\title{
Covid-19 Pandemisi Sürecinde Okul Yöneticiliği: Karşılaşılan Sorunlar ve Çıkarılan Dersler*
}

\section{School Administration during the Covid-19 Pandemic: Challenges and Lessons Learned}

\begin{tabular}{|c|c|}
\hline \multicolumn{2}{|r|}{ Mevlüt Kara, Bayram Bozkurt } \\
\hline Yazar Bilgileri & Öz \\
\hline $\begin{array}{l}\text { Mevlüt Kara } \\
\text { Dr. Öğr. Üyesi, Gaziantep } \\
\text { Üniversitesi, Nizip Eğitim } \\
\text { Fakültesi, Temel Eğitim, } \\
\text { mevlutkara85@gmail.com } \\
\\
\text { Bayram Bozkurt } 9 \\
\text { Dr. Öğr. Üyesi, Gaziantep } \\
\text { Üniversitesi, Nizip Eğitim } \\
\text { Fakültesi, Eğitim Bilimleri, } \\
\text { byrmbzkrt02@gmail.com }\end{array}$ & 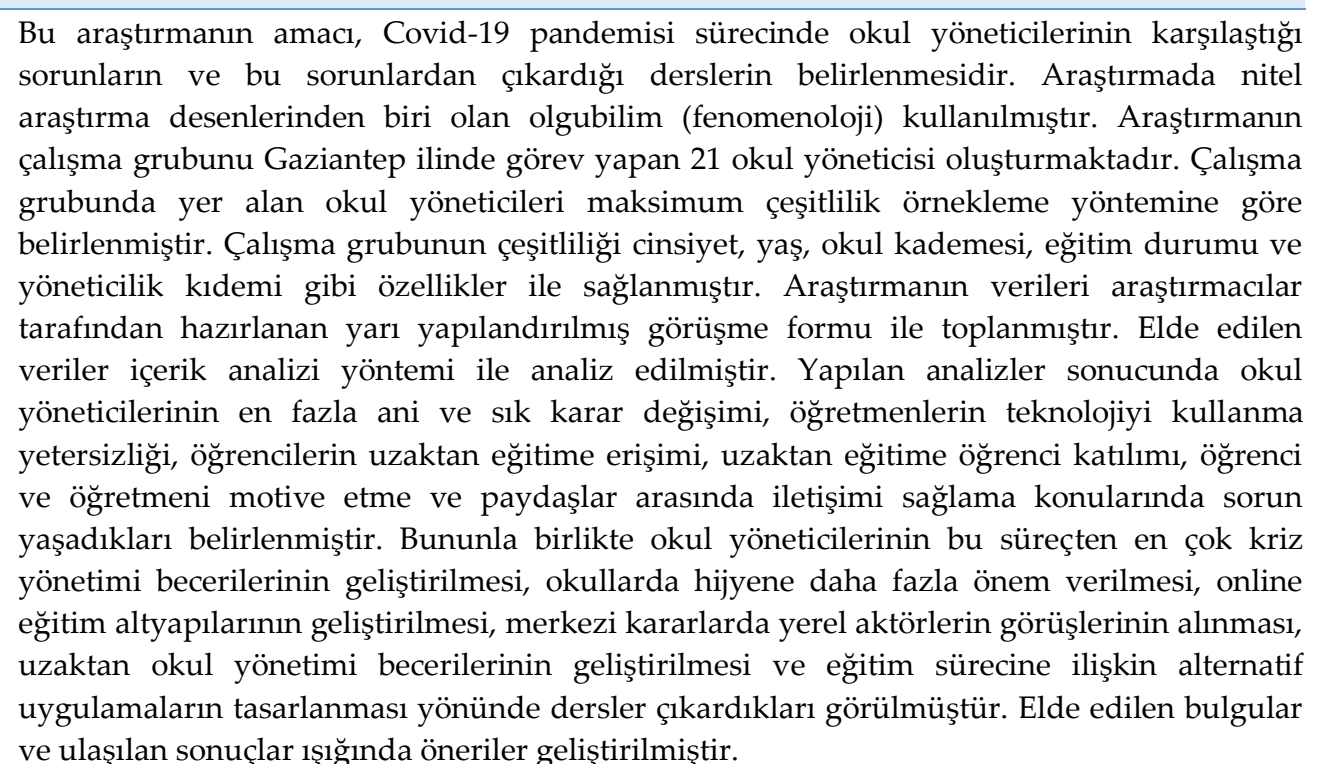 \\
\hline
\end{tabular}

\begin{tabular}{|c|c|}
\hline Makale Bilgileri & ABSTRACT \\
\hline Anahtar Kelimeler & This study aimed at determining the problems encountered by school administrators during \\
\hline Covid-19 & the Covid-19 pandemic and the lessons learned. Phenomenology, one of the qualitative \\
\hline Pandemi & research designs, was used in the study. The study group consisted of 21 school \\
\hline Okul Yöneticileri & administrators working in Gaziantep. The respondents were determined through the \\
\hline Uzaktan Eğitim & $\begin{array}{l}\text { maximum diversity sampling method. The diversity of the study group was based on the } \\
\text { characteristics such as gender, age, school level, educational background, and management }\end{array}$ \\
\hline Keywords & experience. A semi-structured interview form developed by the researchers was used to \\
\hline Covid-19 & collect the research data. The obtained data were analyzed through content analysis. As a \\
\hline Pandemic & result of the study, it was determined that school administrators mostly experienced the \\
\hline School Administrators & problems of sudden and frequent changes of decisions, teachers' inability to use technology, \\
\hline Distance Education & $\begin{array}{l}\text { students' access to distance education, student participation in distance education, } \\
\text { motivating students and teachers, and ensuring communication between the stakeholders. }\end{array}$ \\
\hline Makale Geçmişi & However, it was observed that school administrators mostly learned from challenges to \\
\hline Geliş: 11.07.2021 & develop crisis management skills, to attach more importance to hygiene at schools, to \\
\hline Düzeltme: 08.09.2021 & develop an online education infrastructure, to take the opinions of local actors regarding \\
\hline Kabul: 03.12.2021 & $\begin{array}{l}\text { central decrees, to develop distance school management skills, and to design alternative } \\
\text { practices for the educational procedures. Practical recommendations were given in light of } \\
\text { the obtained findings and results of the study. }\end{array}$ \\
\hline
\end{tabular}

*Bu çalışma, 15-16 Mayıs 2021 tarihlerinde düzenlenen 2. International Congress of Pedagogical Research adlı kongrede sunulan sözlü bildiriden üretilmiştir. 


\section{Giriş}

Tarihsel süreç içerisinde insanlığ1 etkileyen, köklü değişimlere yol açan büyük olaylar, salgınlar gerçekleşmiştir. Covid-19 salgını eğitim sistemlerinin karşılaştığı en büyük problemlerden biri olmuştur (Özer ve Suna, 2020). Dünyadaki tüm ülkeler, eğitim sistemlerini de derinden etkileyen tarihteki en büyük salgınlardan birine hazırlıksız yakalanmış (Daniel, 2020; Wang vd., 2020) ve salgının okullar üzerinden yayılmasını engellemek için okulları kapatmak durumunda kalmıştır (Domenico, Pullano, Coletti, Hens ve Colizza, 2020). Dünya Sağlık Örgütünün (DSÖ) Covid-19‘u 11 Mart 2020 tarihinde küresel salgın ilan etmesi ile birlikte dünya genelinde okullar kapanmış eğitim süreçleri uzaktan ve çevrim içi şekilde gerçekleştirilmiştir (United Nations Educational, Scientific and Cultural Organization [UNESCO], 2020). Yirmi birinci yüzyılın başında tüm dünyayı etkileyen küresel Covid-19 salgını aynı şekilde ülkemizi de etkisi altına almıştır. Türkiye'de Mart 2020 tarihinde ilk vakanın görülmesi ile birlikte okullarda yüz yüze eğitime ara verilmesine, uzaktan ve çevrim içi eğitime geçilmesine karar verilmiştir. Bu süreçte Millî Eğitim Bakanlığı (MEB), Eğitim Bilişim Ağı (EBA) ve Türkiye Radyo Televizyon Kurumu (TRT) tarafından televizyon kanalları aracılığı ile uzaktan eğitim sürecini başlatmıştır.

Tüm dünyada olduğu gibi Türkiye'de de eğitim alanında pandemi süreci ile mücadele etmek için birçok önlem alınmaya çalışılmıştır. EBA ve TRT kanalları aracılığı ile ders içeriklerinin sunulduğu videolar hazırlanmış ve öğrencilere ulaştırılmaya çalışılmıştır. Öğrenci, öğretmen ve velilerde oluşabilecek korku ve kaygıyı önleyici psikososyal destek çalışmaları, telafi eğitimleri, öğrenci başarısının değerlendirilmesinde mevzuat değişiklikleri yapılmıştır (Gençoğlu ve Çiftçi, 2020). Özel eğitime ihtiyaç duyan öğrencileri ve geçici koruma altındaki Suriyeli öğrencileri kapsayacak şekilde destek ve uyum çalışmalarına ağırlık verilmiştir (TEDMEM, 2020). Öğretmenlerin yararlanabileceği içerik videoları ve çevrim içi atölyeler düzenlenmiş, okullarda temizlik ve hijyen kapsamında maske, dezenfektan, önlük, tulum gibi malzemeler temin edilmiştir (MEB, 2020). Ancak yaşanan sorunlara yönelik önlemler alınmaya çalışılsa da küresel çapta yaşanan bu krizin eğitim sistemlerinde yine de birçok sorun oluşturduğu görülmektedir. TEDMEM (2020) raporunda K12 düzeyi kurumlarda yaşanan sorunları farklı boyutlarda ortaya koymuştur ve yaşanan sorunları şu şekilde ifade etmiştir:

- Yönetişim Boyutu: Okulların kapalı olduğu süreçte etkili bir karar modelinin eksikliği sorunlara yol açmıştır. İlgili tarafların görev, yetki ve sorumluluklarındaki belirsizlikler uygulamada sorunlara neden olmuştur.

- Uzaktan Ĕ̆itim Süreci: İnternete erişim ve teknolojik imkânlardaki yetersizlikler uzaktan öğrenmenin etkililiğini olumsuz etkilemiştir. Okulların kapalı olduğu süre uzadıkça öğrenme kaybı da artmıştır. Öğrenme güçlügü olan öğrenciler ve engelli öğrencilerin uzaktan öğrenmesinde sorunlar yaşanmıştır. 
- Okulların Yeniden Açılması Süreci: Planlamalarda sürecin lojistik boyutunda sosyal mesafenin korunması ve hijyen kurallarının uygulanması ile ilgili tedbirlerin uygulanabilirliği noktalarında sorunlar yaşanacağı tahmin edilmektedir.

Öte yandan Gençoğlu ve Çiftçi (2020) uluslararası raporlardan elde ettiği sonuçlardan eğitim alanında yaşanan sorunları;

- Pandemik risklerden dolayı okula dönüş senaryolarının belirsizliğini koruması,

- Ebeveynlerin iş durumu nedeniyle çocuklara bakamaması,

- Okumaz yazmaz ebeveynlerin çocuklarının öğrenmelerini destekleyememesi,

- Öğrenciler arası başarı farklılıklarının ve öğrenme açıklarının artması,

- Uzaktan eğitim platformlarını kullanmadaki beceri yetersizlikleri,

- Tüm öğretmenlerin uzaktan eğitim için gerekli becerilere sahip olmaması,

- Düşük gelir grupları için okulda sağlanan beslenme imkânlarından mahrum kalmak, şeklinde ifade etmiştir.

Salgına ani ve hazırlıksız yakalanma ile birlikte bu soruna yönelik çözüm olarak uzaktan ve çevrim içi eğitime geçmek beraberinde birçok sorunu da getirmiştir (Morgan, 2020; WHO, 2020). Salgın sürecinin yarattığı belirsizlik, kriz durumu ve sürecin öngörülememesi okulların karşılaştığı en büyük sorunlar haline gelmiştir (Zizek, 2020). Okullar bu hızlı değişime hazırlıksız yakalanmışken, okul yöneticilerinin odak noktalarını ve sorun çözme yöntemlerini hızla değiştirerek eğitim sürecindeki aksaklıklara liderlik etmeleri gerekmektedir (Keleş, Atay ve Karanfil, 2020). Razik ve Swanson (2001) ani gelişen kriz durumlarında kurumların ve paydaşların amaçlara ulaşması bakımından kriz yönetim süreçlerinde etkili liderlik becerilerinin önemli olduğunu vurgulamaktadır. Okul yöneticileri salgının ortaya koyduğu kriz süreci boyunca çeşitli sorunlarla mücadele etmek zorunda kalmaktadır. Pandemi ile yoğunlaşan uzaktan eğitim sürecinde öğrencilerin ve ailelerin internete erişim sorunu (Metcalfe ve Perez, 2020), öğrencilerin bilgisayar, tablet gibi teknolojik donanımlarının yetersizliği (Harris, 2020), öğrencileri motive etme ve iletişim sorunları (Çakın ve Külekçi-Akyavuz, 2020), belirsizliğin yarattı̆̆ı kaygı ve iletişim eksikliği (Keleş vd., 2020), öğretmenlerin uzaktan eğitim sürecine yönelik yetersizliği (Burke ve Dempsey, 2020), öğrencilerin derse katılımının yeterince sağlanamaması, ölçme değerlendirmenin tam olarak yapılamaması (Saygı, 2021) gibi birçok sorunla karşılaşıldı̆̆ı görülmektedir. Kavrayıcı ve Kesim'in (2021) çalışmasında okul yöneticileri bütçe, hijyen koşulları ve öğrencilerin sosyal ve duygusal gelişimleri konusunda problem olduğuna yönelik görüşler belirtmiştir. Konan ve Ulaş’ın (2021) çalışmasında ise okul yöneticilerinin okulların sürekli açılıp kapanması konusundaki tutarsızlık, alınan kararların sürekli değişmesi gibi sorunlar dile getirilmiştir. 
Covid-19 pandemisinin eğitim sistemleri ve okul yönetimleri üzerindeki etkisi hala devam etmektedir. Beklenmedik bir anda ortaya çıkan bu kriz durumu eğitimin uygulayıcısı rolüne sahip olan okul yöneticilerine de önemli görev ve sorumluluklar yüklemiştir. Salgından kaynaklı belirsizlik ve yaşanan ani değişim okul yöneticilerinin eğitim öğretimde yaşanan sıkıntıları giderme konusunda farklı liderlik rolleri sergilemelerini gerektirmiştir. Yapılan bu araştırmanın, okul yöneticilerinin bakış açısıyla Covid-19 pandemisinin eğitim ve okul yöneticiliği üzerindeki etkileri ve bu pandemi sürecinden sonra neler yapılabileceği ile ilgili çalışmalar için bir dayanak oluşturması beklenmektedir. Çalışmanın okul yöneticilerinin pandemi sürecinde yaşadıkları sorunları ve bu sorunlardan ne tür dersler çıkardıkları noktasında eğitim uygulayıcılarına, devam eden pandemi sürecinde ve sonrasında neler yapılacağı konusunda politika yapıcılara veri sağlayacağı söylenebilir. Ayrıca çalışmadan elde edilen bulgular ve sonuçların okul yöneticilerinin yetiştirilmesi sürecinde, kriz durumlarında hangi mesleki yeterliliklerin kazandırılması konusunda hem eğitim yönetimi uzmanlarına hem de politika yapıcılara fikir vermesi beklenmektedir. Öte yandan mevcut araştırmanın yeni akademik çalışmalara zemin hazırlaması ve alanyazına katkıda bulunması açısından önem arz ettiği düşünülmektedir.

\section{Araştırmanın Amacı}

Bu araştırmada, okul yöneticilerinin Covid-19 pandemisi sürecinde karşılaştıkları sorunlar ve bu sorunlardan çıkardıkları derslerin incelenmesi amaçlanmaktadır. Bu kapsamda araştırmanın amacı doğrultusunda aşağıdaki sorulara yanıt aranmıştır:

1. Okul yöneticilerinin Covid-19 pandemisi sürecinde en çok karşılaştığ1 sorunlar nelerdir?

2. Okul yöneticilerinin Covid-19 pandemisi sürecinde karşılaştığı sorunlardan çıkardıkları dersler nelerdir?

\section{Yöntem}

\section{Araştırmanın Deseni}

$\mathrm{Bu}$ araştırma, nitel araştırma desenlerinden biri olan olgubilim (fenomenoloji) deseni ile tasarlanmıştır. Nitel araştırma, insanların veya grupların deneyimlerini anlamaya çalışan, konu veya durum hakkında derinlemesine bilgi edinmeye dayanan tümevarımsal bir yaklaşımdır (Frankel ve Devers, 2000). Fenomenoloji ise gerçekliği sadece bireysel boyutta ele alarak bireysel deneyimlerin oluşturduğu bakış açısını yansıtır (Ersoy, 2017). Patton (2014) fenomenolojiyi bireysel yaşantıların anlamı ve doğası hakkında derinlemesine anlayış edinilmesi, Creswell ve Poth (2016) ise bireylerin kavram ve olgulardan ortak anlamlar çıkarması şeklinde açıklamaktadır. Bu bağlamda mevcut araştırmada, okul yöneticilerinin yaşadığı kişisel deneyimlerden yola çıkılarak Covid-19 pandemisi sürecinde yaşadıkları sorunların ve bu sorunlardan çıkardıkları derslerin belirlenmesi amaçlanmıştır. 


\section{Çalışma Grubu}

Araştırmanın çalışma grubu Gaziantep ilinde ve farklı okullarda görev yapmakta olan 21 okul yöneticisinden oluşmaktadır. Çalışma grubunda yer alan okul yöneticileri maksimum çeşitlilik örnekleme yöntemine göre belirlenmiştir. Maksimum çeşitlilik, belli bir yapıyı oluşturan değişkenler arasındaki farklılıkları birleştirme imkânı sağlar (Patton, 2014). Çalışma grubunun çeşitliliği cinsiyet, yaş, okul kademesi, eğitim durumu ve yöneticilik kıdemi gibi özellikler ile sağlanmıştır. Çalışma grubunda yer alan katılımcılara ilişkin kişisel özellikler Tablo 1'de verilmiştir.

Tablo 1. Katılımcılara Ait Kişisel Özellikler

\begin{tabular}{|c|c|c|c|c|c|c|c|}
\hline Yönetici & Cinsiyet & Yaş & $\begin{array}{l}\text { Öğrenim } \\
\text { Durumu }\end{array}$ & $\begin{array}{l}\text { Okul } \\
\text { Kademesi }\end{array}$ & $\begin{array}{l}\text { Öğretmenlik } \\
\text { Kıdemi }\end{array}$ & $\begin{array}{l}\text { Yöneticilik } \\
\text { Kudemi }\end{array}$ & Görev \\
\hline $\mathrm{Y} 1$ & Erkek & 31 & Lisansüstü & Ortaokul & 2 yil & 6 yil & Müdür yardımcısı \\
\hline Y2 & Erkek & 43 & Lisansüstü & Ortaokul & 9 y1l & 9 y1l & Müdür yardımcısı \\
\hline Y3 & Erkek & 37 & Lisansüstü & Ortaokul & 8 y1l & 8 yil & Müdür yardımcısı \\
\hline Y4 & Erkek & 52 & Lisans & İlkokul & 18 yil & 7 y1l & Müdür yardımcısı \\
\hline Y5 & Erkek & 48 & Lisansüstü & Lise & 8 yil & 12 yil & Müdür yardımcısı \\
\hline Y6 & Erkek & 43 & Lisans & Ortaokul & $20 \mathrm{y} 1 \mathrm{l}$ & 2 y1l & Müdür yardımcısı \\
\hline Y7 & Erkek & 42 & Lisansüstü & Ortaokul & 5 yil & 12 yıl & Okul müdürü \\
\hline Y8 & Kadın & 34 & Lisansüstü & Ortaokul & 4 yil & 8 yil & Müdür yardımcısı \\
\hline Y9 & Erkek & 44 & Lisansüstü & Lise & $5 \mathrm{y} 1 \mathrm{l}$ & 15 yil & Okul müdürü \\
\hline Y10 & Erkek & 37 & Lisans & İlkokul & 4 yil & 11 yil & Müdür yardımcısı \\
\hline Y11 & Erkek & 31 & Lisans & Ortaokul & 2 yil & 6 y1l & Müdür yardımcısı \\
\hline Y12 & Erkek & 46 & Lisans & İlkokul & 16 yil & 5 y1l & Okul müdürü \\
\hline Y13 & Erkek & 40 & Lisansüstü & Ortaokul & 11 y1l & 7 yil & Okul müdürü \\
\hline Y14 & Erkek & 41 & Lisans & Ortaokul & 15 y1l & 5 y1l & Müdür yardımcısı \\
\hline Y15 & Kadın & 30 & Lisansüstü & Ortaokul & 4 yil & 4 yil & Okul müdürü \\
\hline Y16 & Erkek & 31 & Lisansüstü & Ortaokul & 1 yil & 7 y1l & Müdür yardımcısı \\
\hline Y17 & Erkek & 38 & Lisansüstü & İlkokul & 3 yil & 14 yil & Okul müdürü \\
\hline Y18 & Erkek & 31 & Lisansüstü & İlkokul & 4 y1l & 3 yil & Müdür yardımcısı \\
\hline Y19 & Erkek & 35 & Lisansüstü & İlkokul & 8 yil & 5 y1l & Müdür yardımcısı \\
\hline Y20 & Kadın & 43 & Lisansüstü & Lise & 13 yıl & 8 yil & Müdür yardımcısı \\
\hline Y21 & Kadın & 29 & Lisansüstü & Okulöncesi & 2 yil & 3 yil & Müdür yardımcısı \\
\hline
\end{tabular}

Tablo 1'e göre çalışma grubunda yer alan ve 17'si erkek, 4'ü kadın olan katılımciların 15'i yüksek lisans mezunu ve 6'sı lisans mezunudur. 29-52 yaş aralığında yer alan katılımcılar, 2-15 yıl arası yöneticilik kıdemine ve 2-20 yıl arası öğretmenlik kıdemine sahiptir. Aynı zamanda 11'i ortaokulda, 6'sı ilkokulda, 3'ü lisede, 1'i okul öncesi eğitim kurumlarında çalışan katılımcıların 15'i müdür yardımcısı, 6'sı okul müdürü olarak görev yapmaktadır.

\section{Veri Toplama Aracı ve Süreci}

Araştırma verileri katılımcılar ile yapılan çevrim içi görüşmeler yoluyla toplanmıştır. Yapılacak görüşmeler için araştırmacılar tarafından yarı yapılandırılmış görüşme formu hazırlanmıştır. İki bölümden oluşan görüşme formunun birinci bölümü, araştırmanın amacından ve katılımcılara ait demografik bilgilere yönelik sorulardan oluşmuştur. Görüşme formunun ikinci bölümünde ise araştırmanın amacına uygun biçimde hazırlanan iki adet açı uçlu soru ve 8 adet 
sonda soru yer almıştır. Veri toplama aracı hazırlanırken öncelikle literatür taraması yapılmış ve bu süreçte okul yöneticilerinin karşılaşabileceği sorunlara ilişkin sorular belirlenmiştir. Hazırlanan taslak soru formunun kapsam geçerliğini belirlemek amacıyla Eğitim Yönetimi alanında uzman iki akademisyene gönderilmiştir. Taslak formdaki soruların Türkçe açısından ifade uygunluğu ve anlaşılabilirliği ise Türkçe eğitimi alanında uzman olan bir akademisyen tarafından incelenmiştir. Daha sonra taslak form kullanılarak 3 okul yöneticisiyle pilot uygulamalar yapılmıştır. Uzmanların yaptığı dönütler ve öneriler ile pilot uygulamalar doğrultusunda soru çıkarma ve ekleme işlemleri, soru sıralamasının değiştirilmesi ve soru ifadelerinin dil açısından düzeltilmesi işlemleri yapılarak görüşme formuna son hali verilmiştir.

Araştırmanın verileri tamamen gönüllük esasına dayalı olarak toplanmıştır. Görüşmeler yapılmadan önce sorular katılımcılara gönderilmiş ve ön bilgilendirme yapılmıştır. Görüşmeler 28 ile 64 dakika arasında sürmüştür. Araştırmanın yapıldı̆̆ı süreçte Covid-19 pandemisi nedeniyle okullardaki eğitim süreci uzaktan eğitim şeklinde devam ettiği için görüşmeler çevrim içi ortamda görüntülü sohbet programı aracılı̆̆ıyla yapılmıştır. Daha sonra yapılan görüşmeler yazıya aktarılmış ve katılımcların değiştirmek istedikleri bir kısmın olup olmadığı sorulmuştur. Katılımcılardan gelen dönütler doğrultusunda verilere son şekli verilmiştir.

Araştırma verilerinin toplanabilmesi için Gaziantep Üniversitesi Sosyal ve Beşerî Bilimler Araştırmaları Etik Kurulundan 01.06.2021 tarihli ve 49278 sayılı kararla izin alınmıştır.

\section{Verilerin Analizi}

Araştırmanın amacı doğrultusunda toplanan veriler içerik analizi yöntemiyle analiz edilmiştir. İçerik analizinde; birbirine benzeyen veriler, belirli kavramlar ve temalar çerçevesinde bir araya getirilerek verilerin içinde saklı olabilecek gerçeklerin ortaya çıkarılması amaçlanır (Yıldırım ve Şimşek, 2016). İçerik analizi, ham verileri belirli standartlara ulaştırmak için yapılan kodlama işlemidir (Hsieh ve Shannon, 2005). Bu bağlamda, öncelikle araştırmada görüşme yapılan katılımcılar Y1, Y2, Y3 ... şeklinde adlandırılmıştır. Daha sonra her bir katılımcıdan elde edilen veriler araştırmacılar tarafından kodlanmıştır. Bazı durumlarda katılımcıların sorulara verdiği yanıtlar birden fazla kodun oluşmasına neden olduğu için aynı katılımcının farklı kodlar altında yer aldığı görülebilmektedir. Benzer kodlar bir araya getirilmiş ve temalara ulaşılmıştır. Ulaşılan kodlar arasındaki benzerlik oranının belirlenmesi amacıyla Miles ve Huberman'ın (2015) formülü (Güvenirlik = görüş birliği/(görüş birliği+görüş ayrılı̆̆ı) x 100) kullanılmıştır. Bu doğrultuda verilerin \%25'lik bir kısmı nitel araştırmalar yapan Eğitim Yönetimi alanında bir uzmana gönderilerek yeniden kodlaması istenmiştir. Sonuç olarak yapılan kodlamalar arasındaki benzerlik oranının \%91,4 olduğu belirlenmiştir. Bu sonuç, yapılan kodlamaların önemli ölçüde güvenilir olduğunu göstermektedir. Öte 
yandan ulaşılan temalara ilişkin frekans sayıları ve katılımcı görüşlerinden yapılan doğrudan alıntılara da yer verilmiştir.

\section{Geçerlilik ve Güvenirlik}

Nitel araştırmalarda geçerlik ve güvenirliği sağlayabilmek için farklı stratejiler kullanılabilmektedir (Creswell, 2012). Bu çalışmada geçerliği sağlayabilmek için amaçlı örneklem yöntemlerinden biri olan maksimum çeşitlilik örneklemesi (Yıldırım ve Şimşek, 2016) kullanılmıştır. Katılımcıların demografik özellikleri ayrıntılı biçimde betimlenmiştir (Başkale, 2016). Katılımcıların çalışmaya katılımında gönüllük esas alınmıştır. Görüşme yapılan katılımcılar ile uzun süreli etkileşim (Güçlü, 2019) sağlanmıştır. Katılımcılardan elde edilen verilere yönelik katılımcı teyidi (Merriam, 2018) sağlanmıştır. Araştırmanın güvenirliğini sağlamak için ise analiz sürecinde farklı araştırmacıların yaptığı kodlamalar karşılaştırılmıştır (McMillian, 2000). Öte yandan araştırma süreci yöntem bölümünde ayrıntılı bir biçimde ele alınmıştır (Shenton, 2004). Bulgular sunulurken katılımcılardan doğrudan alıntılar verilmiştir (Arastaman, Öztürk-Fidan ve Fidan, 2018).

\section{Bulgular}

Araştırmanın bulguları okul yöneticilerinin Covid-19 pandemisi sürecinde karşılaştıkları sorunlar ve bu sorunlardan çıkardıkları dersler olmak üzere 2 bölüm halinde sunulmuştur.

\section{Okul Yöneticilerinin Covid-19 Pandemisi Sürecinde Karşılaştığı Sorunlar}

Katılımcılarla yapılan görüşmeler sonucunda elde edilen verilerin analiz edilmesi sonucunda okul yöneticilerinin Covid-19 pandemisi sürecinde karşılaştığı sorunlar 8 tema altında toplanmıştır. Bu temalara ilişkin bilgiler Şekil 1'de verilmiştir.

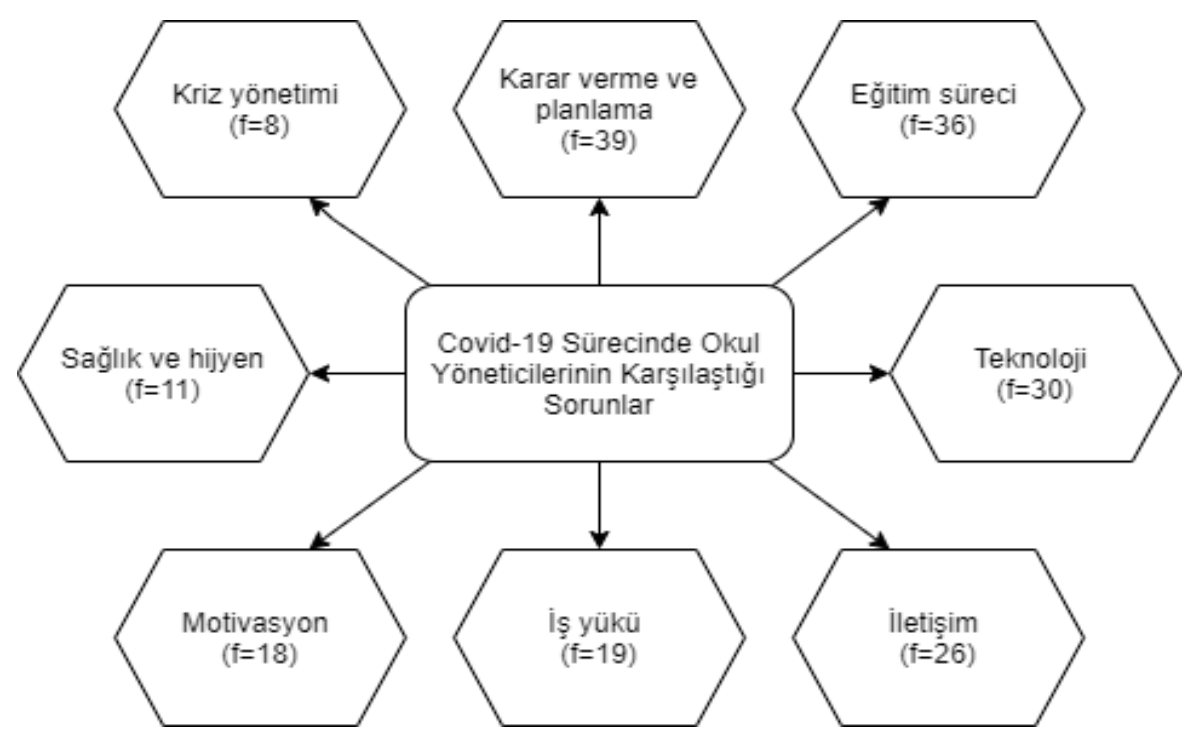

Şekil 1. Okul Yöneticilerinin Covid-19 Pandemisi Sürecinde Karşılaştığı Sorunlara İlişkin Temalar

Şekil 1 incelendiğinde, okul yöneticilerinin Covid-19 pandemisi sürecinde karşılaştığı sorunların 8 temada toplandığı görülmektedir. Bu temalarda yer alan kodlar Tablo 2'de verilmiştir. 
Tablo 2. Okul Yöneticilerinin Covid-19 Pandemisi Sürecinde Karşılaştığı Sorunlara İlişkin Kodlar

\begin{tabular}{|c|c|c|}
\hline Tema & Kodlar & Katılımcılar \\
\hline \multirow{10}{*}{$\begin{array}{l}\text { Karar Verme } \\
\text { ve Planlama }\end{array}$} & Kararların açık ve net olmaması & Y2, Y8, Y9, Y12, Y15, Y17, Y18, Y20, Y21 \\
\hline & Kararların geç alınması & Y2, Y13, Y14, Y15, Y17, Y19, Y20, Y21 \\
\hline & Bütçe sorunu & Y1, Y8, Y9, Y11, Y17 \\
\hline & Ani ve sık karar değişimi & $\mathrm{Y} 1, \mathrm{Y} 2, \mathrm{Y} 6, \mathrm{Y} 15$ \\
\hline & Sinıf sayılarının yetersiz olması & Y5, Y8, Y15, Y19 \\
\hline & Okullar arası uygulama farklılıkları & Y2, Y9, Y19 \\
\hline & Planlama sorunu & $\mathrm{Y} 1, \mathrm{Y} 16$ \\
\hline & Paydaşların kararlara katılım sorunu & $\mathrm{Y} 1, \mathrm{Y} 11$ \\
\hline & Kararların yönetmeliklerle çelişkili olması & Y2 \\
\hline & Okulların kapatılması & Y5 \\
\hline \multirow{10}{*}{ Ĕ̆itim Süreci } & Uzaktan eğitimde öğrenci devamsızlığı & $\begin{array}{l}\mathrm{Y} 2, \mathrm{Y} 8, \mathrm{Y} 10, \mathrm{Y} 11, \mathrm{Y} 13, \mathrm{Y} 15, \mathrm{Y} 16, \mathrm{Y} 17, \mathrm{Y} 18, \mathrm{Y} 19, \\
\mathrm{Y} 20, \mathrm{Y} 21\end{array}$ \\
\hline & Uzaktan eğitime erişim sorunu & Y2, Y5, Y12, Y13, Y17, Y19 \\
\hline & Uzaktan eğitimde denetim sorunu & Y5, Y9, Y16, Y19 \\
\hline & Sosyal gelişimin eksik kalması & $\mathrm{Y} 12, \mathrm{Y} 18, \mathrm{Y} 19$ \\
\hline & Öğrenme eksikliği oluşması & Y5, Y12, Y16 \\
\hline & Akademik başarının düşmesi & Y14, Y16, Y19 \\
\hline & Uzaktan eğitimde veli desteğinin yetersizliği & Y5, Y9 \\
\hline & Yöneticilerin uzaktan eğitimi yönetme tecrübesizliği & Y9 \\
\hline & Ölçme ve değerlendirme sorunu & Y9 \\
\hline & Yüz yüze eğitimde öğrenci devamsızlığı & Y12 \\
\hline \multirow{9}{*}{ Teknoloji } & İnternete erişim sorunu & $\mathrm{Y} 2, \mathrm{Y} 8, \mathrm{Y} 10, \mathrm{Y} 14, \mathrm{Y} 16, \mathrm{Y} 18, \mathrm{Y} 19$ \\
\hline & Öğrencilerin teknolojik donanım yetersizliği & Y11, Y12, Y5, Y16, Y18, Y20 \\
\hline & Tablet dağıtım sorunu & Y2, Y8, Y15, Y16, Y19 \\
\hline & Öğretmenlerin teknolojiyi kullanma yetersizliği & Y1, Y8, Y18, Y19 \\
\hline & Ailelerin teknolojik donanım yetersizliği & $\mathrm{Y} 2, \mathrm{Y} 8, \mathrm{Y} 9$ \\
\hline & Uzaktan eğitim altyapısının yetersiz olması & Y8, Y10 \\
\hline & Çalışanların değişime uyum sağlayamaması & Y1 \\
\hline & Velilerin teknolojiyi kullanamaması & Y8 \\
\hline & Öğretmenlerin teknolojik donanım yetersizliği & Y9 \\
\hline \multirow{7}{*}{ İletişim } & Okul aile iş birliğini sağlayamama & Y1, Y5, Y6, Y9, Y14, Y16, Y17, Y18, Y21 \\
\hline & Öğrenci ve ailelerle iletişim sorunu & Y1, Y2, Y6, Y11, Y14, Y15, Y21 \\
\hline & Öğretmenlerle iletişim sorunu & Y2, Y14, Y15, Y19 \\
\hline & Koordinasyon sorunu & $\mathrm{Y} 1, \mathrm{Y} 2, \mathrm{Y} 18$ \\
\hline & Yabancı uyruklu öğrencilerle iletişim sorunu & $\mathrm{Y} 2$ \\
\hline & Paydaşlar arasında oluşan güvensizlik & Y8 \\
\hline & Yöneticilere dönüt verilmemesi & Y20 \\
\hline \multirow{7}{*}{ İş Yükü } & Ders programı hazırlama sorunu & Y2, Y5, Y6, Y7, Y8, Y15, Y19, Y20 \\
\hline & Yöneticilerin iş yükünün artması & $\mathrm{Y} 6, \mathrm{Y} 8, \mathrm{Y} 19, \mathrm{Y} 20$ \\
\hline & Salgınla mücadelede görevlendirilme & Y3, Y6, Y9 \\
\hline & Zamanı yönetememe & Y1 \\
\hline & Üst yönetim tarafından sık sık veri istenmesi & Y6 \\
\hline & Esnek çalışmanın yarattı̆̆ sorunlar & Y6 \\
\hline & Öğretmenlerin iş yükünün artması & Y15 \\
\hline \multirow{3}{*}{ Motivasyon } & Öğretmen motivasyonunu sağlayamama & Y3, Y5, Y7, Y9, Y11, Y14, Y16, Y17, Y19, Y20 \\
\hline & Öğrenci motivasyonunu sağlayamama & Y5, Y7, Y8, Y9, Y11, Y14, Y19 \\
\hline & Veli motivasyonunu sağlayamama & Y9 \\
\hline \multirow{7}{*}{$\begin{array}{l}\text { Sağllk ve } \\
\text { Hijyen }\end{array}$} & Paydaşlarda oluşan kaygı ve stres & Y5, Y11, Y15, Y20 \\
\hline & Maske-mesafe-temizlik kuralına uyulmaması & Y4, Y7 \\
\hline & Temizlik ve hijyen sorunu & $\mathrm{Y} 2$ \\
\hline & Temizlik malzemesi temin sorunu & $\mathrm{Y} 2$ \\
\hline & Yöneticilerin virüsten korunma sorunu & $\mathrm{Y} 3$ \\
\hline & Yöneticilerin psikolojik destek verememesi & Y9 \\
\hline & Yöneticilere mobbing uygulanması & Y20 \\
\hline \multirow{3}{*}{ Kriz Yönetimi } & Pandeminin yarattığı belirsizlik & Y2, Y8, Y12, Y17, Y20 \\
\hline & Salgına hazırlıksız yakalanma & $\mathrm{Y} 2, \mathrm{Y} 8$ \\
\hline & Pandemi sürecinin öngörülememesi & $\mathrm{Y} 2$ \\
\hline
\end{tabular}




\section{Karar Verme ve Planlama:}

Okul yöneticileri Covid-19 pandemisi sürecinde karar verme ve planlamaya ilişkin çoğunlukla kararların açık ve net olmaması ile kararların geç alınması sorunlarıyla karşılaşmışlardır. Bu süreçte kararların merkezden (Millî Eğitim Bakanlığı) alınması nedeniyle birçok sorunla karşılaşıldığı anlaşılmaktadır. Bu yönde görüş belirten bazı katılımcıların ifadeleri aşağıda verilmiştir.

Y2: "Süreçte biz önümüzü net göremiyoruz. Bir de Bakanlı̆̆ımız tarafından alınan ani kararlar ve bu alınan kararların da net olmaması bizim işimizi daha da zorlaştırıyor. Bu durum bu gün bile hala devam ediyor."

Y15: “... Yani bizi bu dönemde en çok zorlayan nokta bürokratik süreçler oldu. Evet, süreç çok yeniydi, çok bilinmezdi ama Bakanlığın çok sık karar değiştirmesi, her gün farklı kararlar alıp bunların anında uygulamaya geçirilmesi yönündeki yazıları bizi ciddi anlamda sıkıntıya soktu. Karar alırken düşünmeye ya da doğru düzgün planlama yapmaya fırsatımız olmadı. Bakanlık yazıları ve alınan kararların bize aktarılması da son derece geç oldu bu süreçte."

Bu temada okulların yeterli bütçeye sahip olmaması, kararların uygulanmasında okullar arasında farklılıklar olması ve paydaşların kararlara katılımının sağlanmaması ön plana çıkan diğger sorunlardır.

\section{Ĕgitim Süreci:}

Covid-19 pandemisi sürecinde uzun bir süre okulların kapatılması nedeniyle dersler uzaktan eğitim yapılarak işlenmeye çalışılmıştır. Okul yöneticilerinin, öğrencilerin eğitimine ilişkin karşılaştıkları birçok sorunun da uzaktan eğitim ile ilgili olduğu görülmektedir. Bu süreçte okul yöneticileri uzaktan eğitime öğrenci devamının sağlanamaması, öğrencilerin uzaktan eğitime erişememesi, uzaktan eğitimi denetleme ve yönetme zorlukları ve velilerin uzaktan eğitim sürecine yeterli desteği vermemesi sorunlarıyla karşılaştıkları belirlenmiştir. Konuya ilişkin bazı yöneticilerin görüşleri aşağıdaki şekildedir.

Y16:" Öğrencilerimiz için yaptığımız online ders planlamasına otuzar kişilik sınıflardan dört ya da beş kişinin daimi aktif katılım gösterdiği öğretmenlerimizden aldı̆̆ımız verilerle sabittir. Devam ya da devamsızlık yaptırımı bu dönemde geçerli olmadı̆̆ından herhangi bir derse katılım yaptırımı da uygulayamıyoruz. Öğretmenlerimizden bu konu ile ilgili oluşturduğumuz katılım formuna günlük derse katılan öğrenci sayılarını girmelerini istedik. Ne yazık ki dijital ortamda tüm şubelerden elde ettiğimiz veriler bizi haklı çıkarmaktadır."

Uzaktan eğitime ilişkin sorunların dışında, Covid-19 pandemisi sürecinde okul yöneticileri öğrencilerin sosyal gelişimlerinin eksik kalması ve öğrenme eksikliklerinin oluşması sorunlarıyla karşılamışlardır. İki okul yöneticisinin bu yöndeki görüşleri aşağıda verilmiştir.

Y18: “...̈̈̆grencilerin dönem içerisinde gerçekleştirdiği sportif faaliyetler, yarışmalar, sergi vb. çalışmaları bu dönemde gerçekleştiremedik. Bunların öğrencilerin sosyal yönünü geliştirmek açısından gerekli olduğunu düşünmekteyim." 
Y16: "Bu dönemde okulların kapatılması ve yüz yüze eğitimden online eğitime geçişler öğrencilerin ders kazanımları açısından eksik öğrenme tecrübelerini de beraberinde getirmiştir."

\section{Teknoloji:}

Bu süreçte okul yöneticileri çoğunlukla paydaşların teknolojik donanım sorunlarıyla karşı karşıya kalmıştır. Bu sorunlar içerisinde öğrenci, aile ve öğretmenlerin teknolojik donanım yetersizliği, internete erişim ve tablet dağıtımı sorunları ön plana çıkmaktadır. Bu konulara yönelik yönetici görüşleri aşağıdaki biçimdedir.

Y17: "Bu süreçte öğrenciler açısından yaşadığım en büyük sorun bir kenar mahalle okulunda, dezavantajlı bir bölgede, yönetici olmamdan kaynaklı bir sorun. Şöyle ki öğrencilerin evlerinde internet olmadığı için uzaktan eğitime erişim imkânları çok zayıf."

Y18: "Öğretmenler açısından yönetim sorunlarına değinecek olursak öncelikle öğretmenlerimizin teknoloji yeterliliğini sağlayamadığımızı düşünüyorum."

Y19: “Özellikle sosyo-ekonomik olarak nispeten geri olan bölgelerde/hanelerde evde bir adet akıllı telefonun olması hanedeki birden fazla öğrencinin dönüşümlü olarak derse katılmalarına sebep olmuştur."

Teknoloji açısından okul yöneticilerinin bu süreçte karşılaştığ1 diğer bir sorun ise paydaşların (öğrenci, öğretmen, veli) teknolojik aygıtları kullanmada yetersiz kalmalarıdır. Konuya ilişkin yönetici görüşleri aşağıdaki gibidir.

Y1: "Teknolojik anlamda bilgi eksikliği ve yetersizlik genel anlamda karşımıza çok çıktı. Bilgi teknolojisi çağında hızlı bir değişim ve dönüşüm ortamı yaratmaya çalışsakta eksiklikler ve tecrübesizlikler yaşadık."

Y18: “...̈̈ncelikle öğretmenlerimizin teknoloji yeterliliğini sağlayamadığımızı düşünüyorum. Yaş ortalaması yüksek bir okulda görev yapıyorum ve öğretmenlerimizin teknolojiyle arasının iyi olduğunu söyleyemem. Bu nedenle uzaktan öğretim programların aktif kullanmaların sağlayamadığımızı söyleyebilirim."

\section{İletişim:}

Okul yöneticilerinin bu süreçte iletişim açısından karşılaştıkları sorunlar içerisinde okul-aile iş birliğini sağlayamama ön plana çıkmaktadır. Bu soruna yönelik bazı okul yöneticilerinin görüşleri şu şekildedir:

Y14: “...şu dönemde bizim öğretmenden daha fazla ihtiyaç duyduğumuz kesim velidir. Fakat az sayıda veli dışında öğrencisine ve bize destek veren veli yok, hatta bilgilendirme mesajları attığımız zaman rahatsız olup gruptan çıkanlar bile oluyor. Bizimle iletişim halinde olan ve çocuğunu evde takip eden velilerin öğrencileri başarıl olurken ilgisiz velinin çocuğu yüz yüze eğitimde başarılıyken pandemide çok geride kalıyor."

$\mathrm{Bu}$ süreçte okul yöneticilerinin öğrencilerle, ailelerle ve öğretmenlerle iletişim sorunları yaşadıkları görülmektedir. Aynı zamanda okul yöneticilerinin koordinasyonla ilgili yaşadığı sorunlar da dikkat çekmektedir. Bu konudaki bir okul yöneticisinin görüşü aşağıda verilmiştir.

Y17: "En nihayetinde bu sürecin en önemli öznesi olan öğrencilerimize ulaşma noktasında sıkıntılar yaşadık. Biz onlara ulaşamayınca, onlar bize ulaşamayınca yapmış olduğumuz bütün 
planlamalar, çalışmalar çoğu zaman boşa gitti. Bir eğitim yöneticisi olarak en fazla enerjiyi iletişim noktasında harcamama rağmen bu yolda pek mesafe kat edemedim."

\section{İş Yükü:}

Covid-19 pandemisi sürecinde okul yöneticileri önemli ölçüde iş yüklerinin arttığını ifade etmişlerdir. Özellikle sık sık ders programı hazırlamak zorunda kalmaları, salgınla mücadele faaliyetlerinde görevlendirilmeleri ve üst yönetim tarafından sürekli veri istenmesi iş yükü açısından ön plana çıkan sorunlardır. Bazı okul yöneticileri bu konudaki görüşleri aşağıdaki biçimde ifade etmişlerdir.

Y2: "Bu süreçte en sık ders programı hazırlama sorununu yaşadım. Uzaktan eğitim görecek sinıflara ayrı program, yüz yüze eğitim görecek sinıflara ayr program hazırlıyoruz ve bu programların da birbiri ile çakışmaması gerekiyor. Bununla ilgili bir diğer güçlük ise bu programlarm öğretmen, öğrenci ve velilere iletilmesi ve bu durumun sıklıkla tekrar edilmesi."

Y9: "Ĕ̆itim-öğretim faaliyetleri dışında yürütmek durumunda olduğumuz salgınla mücadele faaliyetlerinde görevli olmamızdan dolayı yaşadığımız iş yoğunluğu bizleri oldukça zorlamıştır."

\section{Motivasyon:}

Okul yöneticileri bu süreçte öğrenci, öğretmen ve veliyi motive etme konusunda sorunlarla karşılaştıklarını ifade etmişlerdir. Bu konudaki yönetici görüşlerinden bazıları aşağıda verilmiştir.

Y9: "Uzaktan eğitime dâhil olan okul yöneticilerinin, öğretmenlerin, öğrencilerin ve velilerin bu konudaki farkındalıklarının, bilgi, tecrübe ve motivasyonlarının yeterince olmaması..."

Y16: "Öğretmenlerimiz her ne kadar normal dönemde verilen görevleri bu dönemde de yerine getirmeye çalışsa da dönemin vermiş olduğu rehavet ortamı görmezden gelinemez. Verilen ders programları ve görevlerde aksaklıklar yaşadığımız oluyor. Bu süreç özellikle birinci sımıf öğretmenlerinin fazlasıyla yıpranmasına ve motivasyonlarının düşmesine sebep olmuştur. Bu durumu kontrol etmek, öğretmenlerin okula bağhılı̆̆ın ve motivasyonların săglamak okul yönetimlerini çok zorlamaktadır."

\section{Să̆lik ve Hijyen:}

Okul yöneticilerinin Covid-19 pandemisi sürecinde karşılaştığı en önemli sorun paydaşlarda oluşan kaygı ve strestir. Aynı zamanda okullarda maske-mesafe-temizlik kuralına uyulmaması ve temizlik ve hijyen sorunlarının yaşanması da dikkat çeken diğer sorunlardır. Konuya ilişkin yönetici görüşleri aşağıdaki gibidir.

Y4: "Öğrencilerin ve velilerin okula maskesiz gelmesi, mesafe kuralına riayet etmemeleri ve hijyen kurallarına dikkat etmemeleri okul yöneticisi olarak beni zor durumda bırakmıştır."

Y8: "Her hafta değişen uygulamalar, ders programları okul yönetiminin imajını veli ve öğretmen gözünde hezeyana uğratmıştır. Bu tutarsızlıklar bazı öğrencilerin süreç içinde kaybolmasına sebep olmuş, paydaşların kaygı düzeyi gün geçtikçe daha da artmaya devam etmiştir." 


\section{Kriz Yönetimi:}

Okul yöneticileri açısından bu sürecin yarattığı belirsizlikten kaynaklı kriz durumu çeşitli sorunlarla karşılaşmalarına neden olmuştur. Aynı zamanda bu sürece hazırlıksız yakalanmaları ve sürecin devamını öngörememeleri yöneticiler açısından karşılaşılan diğer sorunlardır. Konuya ilişkin yönetici görüşleri aşağıdaki gibidir.

Y2: "Bu sürecin en başında tüm dünyada ve ülkemizde olduğu gibi bizim de en büyük sorunumuz pandemiye daha doğrusu salgına hazırlıksz yakalanmak oldu. Kendi adıma bunu daha somut söyleyebilirim. Etki alanı bu kadar geniş olacak bir salgın olabileceğini doğrusu hiç öngörmedim ve kendimi bu konuda tam manasıyla hazırlıksız buldum."

Y17: "Her şeyden önce bilmediğimiz bir süreci yaşıyorduk. Neyi nasıl yapacă̆ımızı süreç içerisinde deneye yanıla öğrendik."

\section{Okul Yöneticilerinin Covid-19 Pandemisi Sürecinde Karşılaştığı Sorunlardan Çıkardıkları Dersler}

Elde edilen verilerin analizi sonucunda okul yöneticilerinin Covid-19 pandemisi sürecinde karşılaştığı sorunlardan çıkardıkları dersler 7 tema altında toplanmıştır. Şekil 2'de bu temalara yönelik bilgiler verilmiştir.

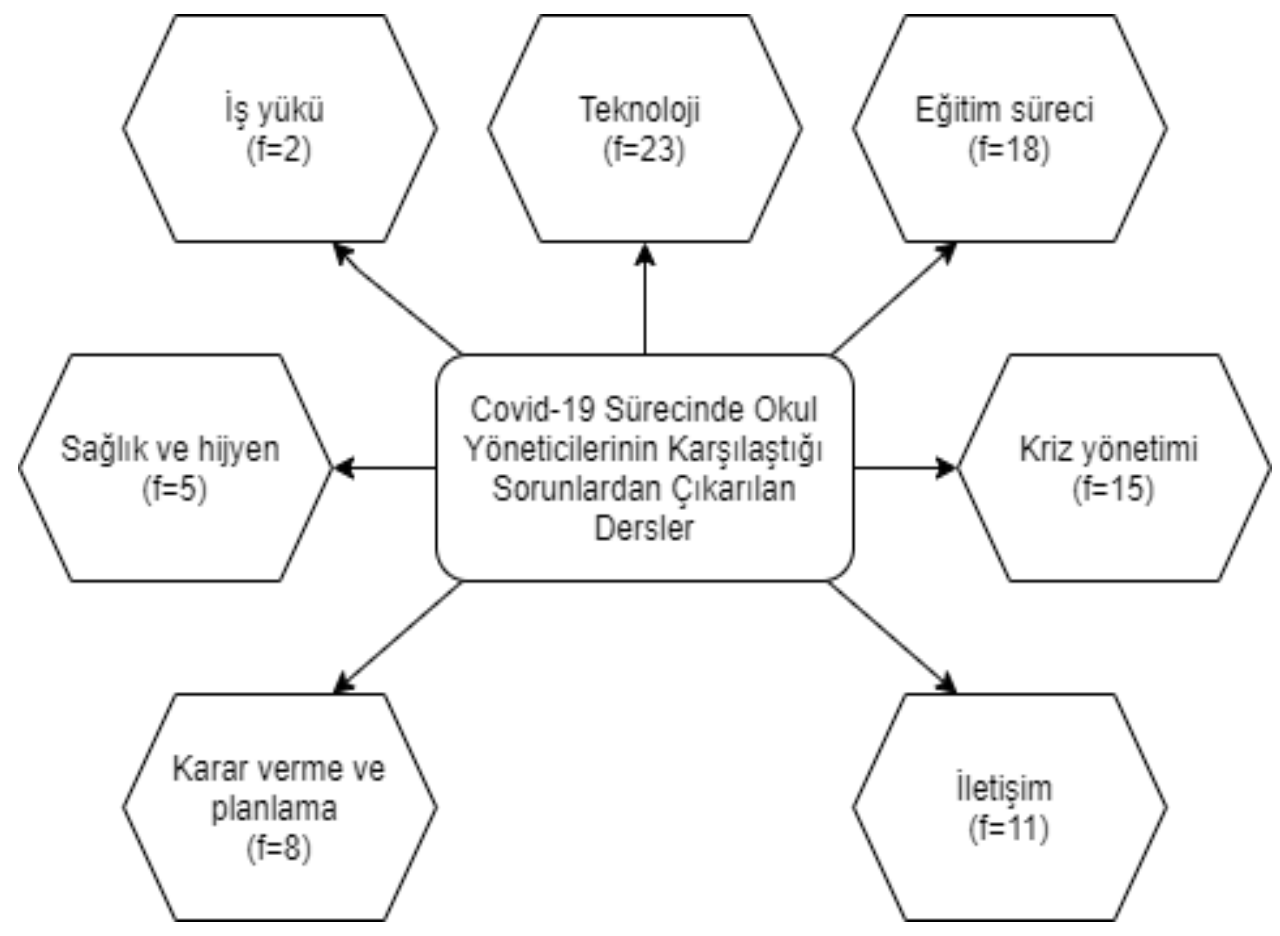

Şekil 2. Okul Yöneticilerinin Covid-19 Pandemisi Sürecinde Karşılaştığı Sorunlardan Çıkardıkları Derslere İlişkin Temalar

Şekil 2 incelendiğinde, okul yöneticilerinin Covid-19 pandemisi sürecinde karşılaştı̆̆ sorunlardan çıkardıkları derslerin 7 temada toplandı̆̆ı görülmektedir. Bu temalarda yer alan kodlar Tablo 3'te verilmiştir. 
Tablo 3. Okul Yöneticilerinin Covid-19 Pandemisi Sürecinde Karşılaştığı Sorunlardan Çıkardıkları Derslere İlişkin Kodlar

\begin{tabular}{|c|c|c|}
\hline Tema & Kodlar & Katılimcılar \\
\hline \multirow{8}{*}{ Teknoloji } & Öğretmenlerin teknolojik yetkinliklerinin geliştirilmesi & Y2, Y9, Y11, Y12, Y13, Y18, Y19 \\
\hline & Öğrencilerin teknoloji okuryazarlı̆̆ı becerilerinin geliştirilmesi & $\mathrm{Y} 1, \mathrm{Y} 6, \mathrm{Y} 8, \mathrm{Y9}, \mathrm{Y} 18$ \\
\hline & Yöneticilerin teknolojik yetkinliklerinin geliştirilmesi & Y17, Y20 \\
\hline & Yöneticilerin teknolojik liderlik becerilerinin geliştirilmesi & Y9, Y17 \\
\hline & Öğrencilerin teknolojik donanım ihtiyaçlarının giderilmesi & Y8, Y18 \\
\hline & Online eğitim altyapılarının oluşturulması & Y8, Y21 \\
\hline & Okulların teknolojik altyapısının güçlendirilmesi & Y8, Y15 \\
\hline & Ailelerin güvenli ve bilinçli internet kullanımı konusunda bilgilendirilmesi & $\mathrm{Y} 12$ \\
\hline \multirow{9}{*}{$\begin{array}{l}\text { Eğitim } \\
\text { Süreci }\end{array}$} & Okulun sosyalleşme açısından gerekliliği & Y5, Y9, Y14, Y15, Y20 \\
\hline & Eğitimde alternatif uygulamalar tasarlama & Y9, Y11, Y13 \\
\hline & Uzaktan eğitimin gerekliliğinin kavranması & Y2, Y9 \\
\hline & Eğitime ilişkin alternatif planlamalar yapma & Y7, Y21 \\
\hline & Yüz yüze eğitimin vazgeçilmezliği & Y5, Y9 \\
\hline & Uzaktan eğitim için sınıf kuralları oluşturulması & Y8 \\
\hline & Dijital ölçme ve değerlendirme araçları geliştirme & Y9 \\
\hline & Çevrim içi mesleki gelişim programları düzenleme & Y9 \\
\hline & Öğrenmede sürekliliğin önemi & Y5 \\
\hline \multirow{4}{*}{$\begin{array}{l}\text { Kriz } \\
\text { Yönetimi }\end{array}$} & Kriz yönetimi becerilerinin geliştirilmesi & Y1, Y6, Y9, Y11, Y12, Y13, Y17, Y19, Y20 \\
\hline & Uzaktan okul yönetimi becerilerinin geliştirilmesi & Y9, Y11, Y16 \\
\hline & Kriz durumlarında okullara bütçe desteği sağlanması & Y15, Y20 \\
\hline & Bakanlığın kriz durumları için planlama yapması & Y19 \\
\hline \multirow{5}{*}{ İletişim } & Okul aile iş birliğinin güçlendirilmesi & $\mathrm{Y} 2, \mathrm{Y} 5, \mathrm{Y9}, \mathrm{Y} 17, \mathrm{Y} 18$ \\
\hline & Paydaşlar arası iletişimin güçlendirilmesi & $\mathrm{Y} 1, \mathrm{Y} 3$ \\
\hline & Alternatif iletişim yolları geliştirme & Y1 \\
\hline & Koordinasyon becerilerinin geliştirilmesi & Y2 \\
\hline & Okul personeli için dijital sosyal ortamların geliştirilmesi & Y16 \\
\hline \multirow{5}{*}{$\begin{array}{l}\text { Karar } \\
\text { Verme ve } \\
\text { Planlama }\end{array}$} & Yerinden yönetim uygulamalarının teşvik edilmesi & Y19, Y20 \\
\hline & Doğru stratejik planlamalar yapma & $\mathrm{Y} 1, \mathrm{Y} 2$ \\
\hline & Karar süreçlerine paydaş katılımının sağlanması & Y2, Y15 \\
\hline & Sınıflarda öğrenci sayılarının azaltılması & Y4 \\
\hline & Acil durumlar için fiziksel hazırlık yapılması & Y16 \\
\hline $\begin{array}{l}\text { Sağllk ve } \\
\text { Hijyen }\end{array}$ & Okullarda hijyene daha çok önem verme & $\mathrm{Y} 1, \mathrm{Y} 2, \mathrm{Y} 3, \mathrm{Y} 4, \mathrm{Y} 16$ \\
\hline \multirow{2}{*}{$\dot{I}_{s ̧} Y \ddot{u} k \ddot{u}$} & Yöneticilerin sosyal sorumluluk anlayışlarının geliştirilmesi & Y9 \\
\hline & Farklı çalışma yöntemlerine ilişkin becerilerin geliştirilmesi & Y9 \\
\hline
\end{tabular}

\section{Teknoloji:}

Okul yöneticileri Covid-19 pandemisi sürecinde yaşadıkları sorunlara bağlı olarak öğretmenlerin ve yöneticilerin teknolojik yetkinliklerinin geliştirilmesi gerektiğini düşünmektedir. Buna ek olarak öğrencilerin teknoloji okuryazarlı̆̆ı becerilerinin ve ailelerin bilinçli internet kullanımı konusunda bilgilendirilmesi gerektiği konusunda dersler çıkarmışlardır. Bu konularda görüş bildiren okul yöneticilerinin ifadeleri aşağıda verilmiştir.

Y13: "Bu süreçten sonra öğretmenlerin dijital gelişimlerini sağlayacak, bilişim teknolojilerine hakim olmalarına olumlu etkisi olacak kurs ve eğitimler alması gerektiği kanısına vardım."

Y17: "Uzaktan eğitim birtakım dijital yeterlilikler gerektirdiğinden eğitim lideri olan okul müdürlerinin bu yeterliliklere sahip olması gerektiğini düşünüyorum."

Y19: "Öğretmenlerin uzaktan eğitim süreçlerini daha etkin kullanmalar için hizmet içi eğitimlerin düzenlenmesi ve uygulamalı bir şekilde sürdürülmesi gerekmektedir." 
Teknoloji konusunda dikkat çeken diğer dersler ise öğrencilerin teknolojik donanım ihtiyacının giderilmesi ve online eğitim altyapılarının oluşturulmasına yöneliktir. Bazı okul yöneticileri bu konudaki görüşlerini aşağıdaki biçimde ifade etmişlerdir.

Y18: “...ne olursa olsun bir öğrencinin artık interneti ve bilgisayarn ya da tableti olmak zorunda. Teknolojinin imkânlarından öğrencilerimizi daha iyi yararlandırmayı bilmeliyiz."

Y8: “Uzaktan eğitim süreci için okul imkanlar doğrultusunda bir platform satın alınarak online eğitim alt yapısı oluşturulabilir ve tüm öğrenciler oraya kaydedilebilir. Okul personeline ciddi bir şekilde bilgisayar okuryazarlığı için eğitim verilebilir."

\section{Ĕ̈itim Süreci:}

Okul yöneticilerinin eğitim sürecine ilişkin pandemiden çıkardıkları en önemli dersin okulun öğrencilerin sosyalleşmesi açısından gerekli olduğudur. Aynı zamanda yüz yüze eğitimin vazgeçilmez olduğu ama uzaktan eğitimin de bundan sonraki süreçte gerekli olduğu belirtilmiştir. Bunun için eğitimde alternatif planlamalar yapılarak eğitim sürecinde farklı uygulamalara yer verilmesi gerektiği ifade edilmiştir. Bu konularda görüş belirten bazı okul yöneticilerinin ifadeleri aşağıda verilmiştir.

Y9: "Bir okul yöneticisi olarak pandemiden sonra alternatif eğitim uygulamaları, eğitim yönetimi uygulamaları, ölçme-değerlendirme uygulamaları konularında farkındahı̆ımı, bilgi ve tecrübemi arttırmam gerektiğini düşünüyorum."

Y20: "Pandemi sonrası aslında okulda nasıl sosyalleşilecek kestiremiyorum. Sosyalleşmeden kastettiğim okul toplumunu bir arada tutan unsurlar ve bu bağların oluşmasina ve gelişmesine yönelik çalışmalar üretmek. Pandemide bence öğrenciler daha bireysel etkinlikler içindeydi. Pandemi, gençlerde yalnızlaşmayı ve sanallı̆̆l daha da artırdı. Bu yönde okulda politikalar çalışılmalı."

\section{Kriz Yönetimi:}

Covid-19 pandemisi okul yöneticileri tarafından bir kriz süreci olarak ifade edilmiş ve okul yöneticileri bu süreci yönetmeye ilişkin becerilerinin yeterli olmadığını ifade etmişlerdir. Bu nedenle pandemi sürecinden çıardıkları en önemli dersin kriz yönetimi becerilerinin geliştirilmesine yönelik olduğu görülmektedir. Aynı zamanda bu süreçte uzaktan eğitim sürecine yönetmek zorunda kalan okul yöneticileri, uzaktan okul yönetimi becerilerinin geliştirilmesi gerektiğini belirtmişlerdir. Bu yönde görüş belirten bazı okul yöneticilerinin ifadeleri aşağıdaki gibidir.

Y17: "Aslında yükseköğretimde var olan fakat temel eğitimde ilk defa karşılaştı̆̆ımız bir olguydu uzaktan eğitim. Maalesef bütün dünya gibi biz de bu krize hazırlıksı yakalandik. Süreç içerisinde deneye yanıla doğruyu bulmaya çalıştık. Her şeyden önce eğitim yöneticilerine kriz anında nasıl davranılması gerektiği konusunda bir eğitim verilmesi gerektiğini düşünüyorum."

Y19: "Bu süreçte okul yönetiminin stabil bir süreçten ziyade dinamik bir süreç olduğunu daha iyi gördük. Bu çerçevede okul yöneticilerinin kendilerini sürekli geliştirmesi ve kriz yönetimine hazır olmalarının gerekliliği daha net bir biçimde ortaya çıkmıştır." 


\section{Iletişim:}

Okul yöneticilerinin bu süreçten iletişime yönelik çıkardıkları dersler içerisinde okul-aile iş birliğinin güçlendirilmesi ön plana çıkmaktadır. Bu süreçte okul yöneticileri paydaşlar arasındaki iletişimin ve koordinasyonun okul yönetimi açısından oldukça önemli olduğunu bir daha deneyimlemiş ve bunun için de alternatif iletişim yolları geliştirilmesi gerektiğini ifade etmişlerdir. Bu konulara yönelik bazı okul yöneticilerinin görüşleri aşağıdaki şekildedir.

Y1: "Pandemiden çıkardığımız en önemli ders ise insanlar arası iletişim ve etkileşimin önemi oldu. İletişim olmadan değişim ve eşgüdümün olmayacağın tecrübe etme firsatımı oldu. Öğrenen bir örgüt olan okulumuzun ortak amaçlarına ulaşabilmesinin en iyi yolunun etkili bir iletişim ve etkileşimden geçtiğini öğrendik."

Y5: "Okul veli iş birliğinin çok önemli olduğu, veliyi eğitim öğretimin her aşamasına dahil etmenin çok gerekli bir durum olduğu pandemi sürecinde çok daha iyi anlaşılmıştır."

Y9: "Daha sonra ortaya çıkabilecek kriz durumlarında okul-veli iş birliğini teşvik edecek uygulamalar konusunda bilgi ve tecrübe edinmem gerektiğini fark ettim."

\section{Karar Verme ve Planlama:}

Okul yöneticileri bu süreçte merkeziyetçi yapıdan olumsuz etkilenmişlerdir. Bundan dolayı yerinden yönetim uygulamalarının teşvik edilmesi gerektiğini ve karar alma süreçlerine paydaş katılımının sağlanması gerektiğini belirtmişlerdir. Bunların dışında okulların stratejik plan yapma süreçlerine daha fazla önem vermeleri gerektiği okul yöneticileri tarafından ifade edilmiştir. Konuya ilişkin bazı yöneticilerin görüşleri aşağıdaki şekildedir.

Y15: "Bence ülke yöneticilerinin ve özellikle karar vericilerin sahadaki eğitim yöneticilerine kesinlikle danışması gerekiyor. Her ilçe ve il düzeyinde farklı hizmet alanları, farklı sosyokültürel çevrelerden farkl okul türleri ve kademelerinden, okul müdürlerinden oluşan komisyonlar kurulup yaşanabilecek sıkıntılara yönelik görüs ve çözüm önerilerini Bakanliğa iletebileceği bir sistem geliştirilmelidir. Merkezdeki bir okulun şartlarına, imkanlarına bakarak karar vermek kolaydır. Ben verilen kararların ülkenin dört bir yanındaki okullarda da uygulanabilirliğini, uygulama birliğini sağlamasını önemli olduğunu düşünüyorum."

Y20: "Pandemide her okul aynı gibi düşünüldü. Oysa her okul birçok yönüyle birbirinden farkl. Tek merkezden yönetim okul yöneticilerinin işini çok zorlaştırdı. Mesela sınav tarih aralı̆̆ı verilmesi. Biz nasıl, ne şekilde să̆lıklı bir sınav yapacağımızı biliriz. Valiliklere bırakılabilirdi. Bazı kararlar bırakıldı ama geç oldu. Okulları okullara bıraksınlar. Geçen eğitim öğretim yılında bizim okuldan çok iyi kararlar çıkmıştı."

\section{Sağllk ve Hijyen:}

Okul yöneticileri Covid-19 pandemisinden sonra okullarda hijyene daha fazla önem verilmesi gerektiğini düşünmektedirler. Bu konuda bazı okul yöneticilerinin görüşleri aşağıdaki şekildedir.

Y16: "Bu dönemde okul içi sağllk ve temizlik kurallarnna daha fazla önem gösterdik. Gerekli yerleri afişlerle ve uyarı levhaları ile donattık. Aslında her zaman dikkat edilmesi gerek birçok hususu gözden geçirdiğimize şahit olduk. Pandemi sonrası sağlık ve temizlik konusunda tıpkı bu dönemdeki gibi dikkatli davranmamız konusunda bilinçlendiğimizi düşünüyorum." 
Y3: "Bu virüsün mikroplar yoluyla insanlara hızlı bir biçimde bulaşması eğitimi önemli ölçüde sekteye uğrattı. Tabi bu durum okul yöneticisi olarak bizlerin temizlik ve hijyen gibi konulara akademik başarı kadar önem vermemiz gerektiğini gösterdi."

Işs Yükü:

Pandemi sürecinde salgınla mücadele faaliyetlerinde görev alan okul yöneticileri, bundan sonraki süreçte sosyal sorumluluk konularında kendilerini geliştirmeleri gerektiğini düşünmektedirler. Öte yandan bu süreçte sık sık okul dışından çalışmak zorunda kalmaları, yöneticilere farklı çalışma yöntemlerine ilişkin becerilerinin geliştirilmesi gerektiğini göstermiştir.

Y9: "Pandemi sürecinde salgınla mücadele faaliyetlerinde yoğun bir biçimde görev aldım. Bu durum okul yöneticilerinin görevlerinin okulla sınırlı olmadığını bana gösterdi. Bundan dolayı toplumsal duyarlılık ve sosyal sorumluluk çalışmalarında daha çok yer almayı düşünüyorum." Y9: "Farklı çalışma yöntemleri konusunda (esnek çalışma, uzaktan çalışma) bilgim ve tecrübem arttı."

Araştırma bulguları okul yöneticilerinin Covid-19 pandemisi sürecinde mevcut sorunlarının yanında daha önce karşılaşmadıkları çeşitli sorunlarla da karşı karşıya kaldıklarını göstermektedir. Yaşanan bu sorunlara çözüm bulma sürecinde okul yöneticilerinin hem okul yönetimi ve işleyişi hem de sahip olmaları gereken yeterlikler açısından ihtiyaçlarına ve eksikliklerine yönelik birçok ders çıkardıkları görülmüştür. Okul yöneticilerinin bu süreçten çıkardıkları derslerin, mesleki gelişimleri ve kriz durumlarında okul yönetimi açısından birçok somut öneriyi de içerdiği söylenebilir.

\section{Tartışma ve Sonuç}

$\mathrm{Bu}$ araştırmanın temel amacı doğrultusunda, okul yöneticilerinin Covid-19 pandemisi sürecinde karşılaştığı sorunlar ve bu sorunlardan çıkardıkları dersler olmak üzere 2 soruya yanıt aranmıştır. Araştırmanın bulguları incelendiğinde, okul yöneticilerinin Covid-19 pandemisi sürecinde karşılaştığı sorunların karar verme ve planlama, eğitim süreci, teknoloji, iletişim, iş yükü, motivasyon, sağlık ve hijyen, kriz yönetimi olmak üzere 8 temada ve karşılaştıkları sorunlardan çıkardıkları derslerin ise teknoloji, eğitim süreci, kriz yönetimi, iletişim, karar verme ve planlama, sağlık ve hijyen, iş yükü olmak üzere 7 temada toplandığı görülmektedir. Dolayısıyla, her iki soruya ilişkin ortaya çıkan temaların önemli ölçüde örtüştüğü söylenebilir. Bundan dolayı, araştırmanın bu bölümünde her iki soruya ilişkin ortaya çıkan temalar birbirleriyle ilişkilendirilerek tartışılacaktır.

Covid-19 pandemisinin gerek toplumsal hayat gerek eğitim örgütleri açısından yaratmış olduğu belirsizlikler okul yöneticilerinin kriz yönetimi becerilerini oldukça önemli hale getirmiştir. Pandemi sürecinin tüm insanlar için olduğu gibi okul yöneticileri açısından da kişisel, toplumsal ve mesleki açıdan ilk defa karşılaşılan bir durum olması, çeşitli belirsizlikleri de beraberinde getirmesine neden olmuştur. Harris ve Jones'a (2020) göre, okul yöneticileri pandemi sürecinde güvenlik ağ1 olmayan bir ip üzerinde yürümektedirler ve kendilerine yol gösteren herhangi bir örnek veya rehber 
bulunmamaktadır. Bununla birlikte okul yöneticilerinin pandemi sürecine hazırlıksız yakalanmaları ve sürecin devamını öngörememeleri bu krizin yönetimini daha da zorlaştırmıştır. Bu nedenlere bağlı olarak okul yöneticileri, kriz yönetimi ve uzaktan okul yönetimi becerilerinin geliştirilmesi gerektiğini ifade etmişlerdir. Araştırmada ulaşılan bu sonuçlar, okul yöneticilerinin kriz yönetimi açısından kendilerini yetersiz gördükleri şeklinde yorumlanabilir. Benzer şekilde Aytaç (2020) tarafından yapılan araştırmada da okul yöneticileri kriz yönetimi becerilerinin geliştirilmesine ihtiyaç duyduklarını belirtmişlerdir. Covid-19 pandemisi sürecinde kriz yönetimi açısından okul yöneticilerinin karşılaştığı en önemli sorunlardan biri de karar verme süreçlerine ilişkindir. Küresel ölçekte bir kriz olarak ortaya çıkan Covid-19 pandemisi, ülke içerisinde birçok kurumun birlikte hareket etmesini gerektirdiği için okullar ve okullarla ilgili paydaşlar da merkezi hükümetin ve bakanlıkların kararlarını dikkate alarak hareket etmek durumunda kalmışlardır. Ancak mevcut araştırmanın sonuçları, okul yöneticilerinin Covid-19 pandemisi sürecinde karar alma süreçlerinde okul merkezli yönetim modellerine, yerinden yönetim uygulamalarına, yetki devrine ve yönetsel özerkliğe ihtiyaç duyduğuna işaret etmektedir. Çünkü kriz dönemleri karar vericilerin hızlı karar almalarını ve süreci etkin bir şekilde yönetmelerini gerektirmektedir. Ancak okul yöneticileri Covid19 pandemisi sürecinde Millî Eğitim Bakanlığından gelen emir ve talimatlar doğrultusunda görevlerini yapmışlardır. Merkezi hükümetin ve eğitimden sorumlu olan bakanlığın ani ve sık karar değiştirmesi, alınan kararların açık ve net olmaması veya bazı durumlarda kararların geç alınması gibi faktörlere bağlı olarak Türkiye'deki okul yöneticilerinin karar verme süreçlerinde sorun yaşadığ ortaya çıkmıştır. Bu süreçte sadece alınan kararları uygulama konumunda olan okul yöneticilerinin liderlik vasıflarını sergilemeleri ve çevresindekilere güven vermeleri (Sarı ve Sarı, 2020) mümkün olmamış ve proaktif davranışlar ortaya koyamamışlardır (Kavrayıcı ve Kesim, 2021). Öte yandan okullar arasında uygulama farklılıkları olduğunun belirlenmesi de Millî Eğitim Bakanlığının karar verme süreçlerini sağlıklı bir biçimde işletemediğini ortaya koyan başka bir göstergedir. Covid-19 pandemisi sürecinin geleceğini öngöremeyen ve merkezi hükümete bağlı bir biçimde görevlerini yapmayı sürdüren okul yöneticilerinin eğitim sürecini planlama konusunda da sorunlar yaşadığı tespit edilmiştir. Bu sorunlarla karşılaşan okul yöneticilerinin bu süreçten çıkardıkları en önemli dersler; yerinden yönetim uygulamalarının teşvik edilmesi, doğru stratejik planlamalar yapılması ve okulların acil durumlar için fiziksel olarak hazırlanması gerektiğine ilişkindir.

16 Mart 2020 tarihinden itibaren belli dönemlerde okullar seyreltilmiş biçimde açılsa da okullardaki eğitim süreci 2020-2021 eğitim-öğretim yılının sonuna kadar önemli ölçüde uzaktan eğitim şeklinde devam etmiştir. Araştırmanın sonuçlarına göre, Covid-19 pandemisi sürecinde öğrencilerin uzaktan eğitimde yaptıkları devamsızlık eğitim açısından karşılaşılan en önemli sorundur. Bu süreçte uzaktan eğitim için ihtiyaç olan internetin sağlanamaması, öğrencilerin ve 
ailelerin teknolojik donanım sorunları yaşaması, uzaktan eğitim altyapısının yetersiz olmasından dolayı öğrencilerin uzaktan eğitime erişimde sorunlar yaşadığı mevcut araştırma bulgularından anlaşılmaktadır. Turan (2020) tarafından yapılan araştırmada da benzer şekilde okul müdürlerinin teknik sorunlar, veli duyarsızlığı, öğrencilerin sosyo-ekonomik durumu, devamsızlık sorunu ve teknolojik araç eksikliği nedeniyle uzaktan eğitimin belirlenen amaçlara ulaşmadığını ifade ettiği belirlenmiştir. Araştırmada elde edilen bu sonuç, eğitime erişim açısından öğrenciler arasında yaşanan sosyal adaletsizliklerin Covid-19 pandemisi sürecinde daha da derinleştiğine işaret etmektedir. Millî Eğitim Bakanlığı öğrencilerin bu sorunlarını çözebilmek ve öğrenciler arasında fırsat ve imkân eşitliğini sağlayabilmek için okullarda "EBA Destek Noktaları" kurmuş ve öğrencilere kademeli olarak tablet dağıtımı yapmıştır (MEB, 2021). Ancak öğretmen ve yönetici görüşlerine başvurulmadan merkezi yönetim tarafından belirlenen öğrencilere tabletlerin dağıtılması, okul yöneticileri ile veliler arasında çeşitli sorunlara neden olmuş ve velilerin yöneticilere olan güveni zedelenmiştir. Öte yandan Covid-19 pandemisi sürecinde okuldaki sosyal ortamdan uzak kalan öğrencilerin sosyal gelişimlerinin eksik kaldığı araştırmanın dikkat çekici diğer bir sonucudur. Bu süreçte öğrencilerin sosyal izolasyon ile uzun süre evde kalmaları, sosyal ve duygusal yönden olumsuz etkilere neden olmuştur (Gençoğlu ve Çiftçi, 2020). Diğer yandan mevcut araştırma sonuçları, bu süreçte öğrencilerde öğrenme eksiklikleri oluştuğunu ve akademik başarının düştüğünü ortaya koymaktadır. Öğrencilerin bu süreçte öğrenme kayıpları veya eksikleri ile karşılaştığı farklı araştırmalarda da (Akıncı ve Pişkin-Tunç, 2021; Akkaş-Baysal ve Ocak, 2020; TEDMEM, 2021) vurgulanmıştır. Araştırmada elde edilen bu sonuçlar, öğrencilerin bu süreçten akademik, sosyal ve duygusal olarak olumsuz etkilendiğini ve bu sürecin sonrasında yapılacak olası telafi çalışmalarının oldukça önemli olduğunu göstermektedir. Öte yandan okul yöneticileri, Covid-19 pandemisi sürecinde öğrencilerin sosyalleşmesi açısından okulun gerekliliğini daha iyi bir şekilde kavradıklarını ifade etmişlerdir. Pandemi sonrası eğitim sürecine ilişkin ise her ne kadar yüz yüze eğitim vazgeçilmez olsa da eğitime ilişkin alternatif planlamalar ve uygulamalar tasarlanması gerektiğine ilişkin dersler çıkardıklarını ve uzaktan eğitimin bundan sonraki süreçte tamamlayıcı ve alternatif bir eğitim modeli olarak hayatımızda yer alması gerektiğini vurgulamışlardır.

Öğrencilerin, öğretmenlerin ve velilerin teknolojik donanımlarının yetersiz olmasının yanı sıra karşılaşılan diğer bir sorunun ise bu paydaşların uzaktan eğitim sürecindeki teknolojileri kullanma yetersizlikleri olduğu saptanmıştır. Yılmaz, Güner, Mutlu ve Arın-Yılmaz (2020) teknoloji altyapısı ve donanımı yeterli seviyelerde olmayan öğretmenlerin sürece hazırlıksız yakalandığını, uzaktan eğitim uygulamalarını kullanmada zorluklar yaşadığını ve öğrencilerine yeterli desteği veremediklerini ifade etmiş̧tir. Bu sorun öğretmenlerin uzaktan eğitim derslerinde teknolojiyi etkin bir şekilde kullanmalarını, içerik üretmelerini ve sınıf yönetimini sağlamalarını olumsuz etkileyen bir faktör 
olarak değerlendirilebilir. Öte taraftan okul yöneticilerinin ise uzaktan eğitimi yönetme konusunda tecrübesiz oldukları ve uzaktan yürütülen eğitim etkinliklerini denetleme konusunda sorunlarla karşılaştıkları tespit edilmiştir. Aytaç (2020) tarafından yapılan çalışmada okul yöneticileri uzaktan eğitim sürecinde okullar tarafından kullanılan birbirinden farklı uygulamaların sürecin yönetimi açısından sorun oluşturduğunu belirtmişlerdir. Aynı zamanda okul yöneticilerinin bu süreçteki eğitim faaliyetlerini yönetebilmesi ve denetleyebilmesi için bilgi ve iletişim teknolojilerini üst düzeyde kullanabilmesi gerekmektedir. Bu bağlamda mevcut araştırmada elde edilen bu sonuç, okul yöneticilerinin ilk defa bu tür bir süreç ile karşılaşmaları ve teknolojiyi kullanma yeterliliklerinin düşük düzeyde olması ile ilişkilendirilebilir. Okul yöneticileri karşılaştıkları bu sorunlar doğrultusunda, öğretmenlerin ve okul yöneticilerinin teknolojik yetkinliklerinin, öğrencilerin teknoloji okuryazarlığı becerilerinin geliştirilmesi gerektiğini ve öğrencilerin teknolojik donanım ihtiyaçlarının giderilmesi gerektiğini vurgulamışlardır.

Covid-19 pandemisi sürecinde okul yöneticilerinin karşılaştı̆̆g sorunların önemli bir bölümü de iletişimle ilgilidir. İletişim, insanlar arasında bağlantıyı sağlayan köprü görevi görmektedir. Pandemi sürecinde okul yöneticilerinin eğitim paydaşlarıyla iletişim kurarken kullandıkları araçlar önemli ölçüde değişmiştir. Bu dönemde yüz yüze iletişimin yerini çoğunlukla bilişim teknolojilerine dayalı bir iletişim süreci almıştır. Bu tür bir iletişim, okul yöneticilerinin ve diğer eğitim paydaşlarının çok sık kullandığı ve alışkın oldukları bir iletişim tarzı değildir. Araştırmada, okul yöneticilerinin öğrenciler ve ailelerle iletişim sorunları yaşadıkları için okul aile iş birliğini yeteri kadar sağlayamadıkları ortaya çıkmıştır. Çakın ve Külekçi-Akyavuz (2020) tarafından yapılan araştırmada, öğrencilere ve velilere ulaşılamamasından dolayı öğrencilerin eğitim sürecine ilişkin geri bildirim alınamadığı belirtilmiştir. Bu süreçte yüz yüze iletişimin sağlanamaması, ailelerin internete erişim sorunu yaşaması ve bilişim teknolojilerinin kullanımındaki yetersizlik ortaya çıkan bu sorunun nedenleri olarak düşünülebilir. Diğer yandan iletişim açısından ortaya çıkan önemli sorunlardan birinin de bu süreçte okul yöneticileri ile öğretmenler arasında yeterli ve sağliklı iletişim kurulamaması olduğu belirlenmiştir. Her ne kadar okullardaki eğitimle ilgili süreçleri yöneticiler yönetse de eğitimle ilgili faaliyetleri doğrudan gerçekleştiren eğitim paydaşları öğretmenlerdir. Bu nedenle okul yöneticileri ile öğretmenler arasındaki iletişim, eğitim sürecinin sistemli, programlı ve eşgüdümlü bir şekilde gerçekleştirilmesi açısından büyük önem taşır. Pandemi döneminde öğrenci, öğretmen ve ailelerle yaşanan iletişim sorunları okul yöneticilerinin paydaşlar arasında eşgüdüm sağlayabilmesini de olumsuz etkilemiş ve bahsi geçen paydaşlar arasında güvensizlik ortaya çıkmıştır. Bununla birlikte araştırmada okul yöneticilerinin öğretmen, öğrenci ve veli motivasyonunu sağlama konusunda da çeşitli sorunlarla karşılaştığı ortaya çıkmıştır. Reimers ve Schleicher (2020), bireylerin yaşamlarını ve sağlıklarını önemli ölçüde etkileyen, öğrenci ve öğretmenleri yakından ilgilendiren 
küresel bir sağlık olayının onların motivasyonunu ve çalışmalarını etkileyebileceğini belirtmiştir. Bu süreçte okul yöneticilerinin öğretmen, öğrenci, veli ve yardımcı personel üzerinde desteğini hissettirmesi (Külekçi-Akyavuz ve Çakın, 2020) bu kişilerin istekleri, yaptıkları işten tatmin olmaları ve örgütsel amaçlara ulaşılabilmesi açısından büyük önem taşır. Yapılan çeşitli araştırmalarda da (Keleş vd., 2020; Önan ve Menekay, 2021; Özdoğan ve Berkant, 2020) benzer sonuçlara ulaşıldığı görülmektedir. Araştırmada ulaşılan bu sonuç, okul yöneticilerinin bahsi geçen paydaşlar ile sağlıklı bir iletişim süreci kuramaması, eğitime erişimde yaşanan sosyal adaletsizlikler ve pandemi sürecinden insan psikolojisinin olumsuz etkilenmesi ile ilişkilendirilebilir. Görüldüğü gibi, birçok durumda sorunların çözümü olabilecek iletişim; Covid-19 pandemisi sürecinde ihtiyaç duyulduğu şekilde gerçekleştirilemediği için ortaya çıkan çeşitli sorunların nedeni haline gelmiştir. Bu sorunlarla karşılaşan okul yöneticileri, pandemi sonrası süreçte okul-aile iş birliğinin ve paydaşlar arası iletişimin güçlendirilmesi gerektiğini belirtmişlerdir. Bunun için de alternatif iletişim yollarının ve özellikle de okul personeli için dijital sosyal ortamların geliştirilmesi gerektiğine vurgu yapmışlardır.

Covid-19 pandemisi, dünyanın farklı bölgelerinde çalışan okul yöneticileri açısından çalışma usul ve esaslarının değiştiği ve normal dönemde yapılmayan birçok görevin yerine getirildiği farklı bir dönem olmuştur. Pandemi sürecinde Amerika Birleşik Devletleri'nde görev yapan okul yöneticileri ön cephede yer alarak ihtiyaç duyan ailelere yemek dağıtmış, öğrencilere dizüstü bilgisayar ve tablet getirmiş, sürekli yazdıkları e-postalar ile öğrencilerin moralini üst düzeyde tutmaya çalışmış ve velilerle sürekli iletişim halinde olmuşlardır (Stone-Johnson ve Weiner, 2020). Türkiye'deki okul yöneticileri de pandemi sürecinde paydaşlara yönelik sürekli bilgilendirmeler yapmış, okula aidiyet duygusunu artırmaya yönelik söylemlerde bulunmuş, öğretmenlerle sürekli online iletişim halinde olarak onların sorunlarını, sıkıntılarını dinlemiş, bu süreci kolaylaştıracak etkinlik ve seminerler düzenleyerek öğretmenlerinin motivasyonunu artırmaya çalışmışlardır (Külekçi-Akyavuz ve Çakın, 2020). Bu araştırmada ise okul yöneticilerinin salgınla mücadele faaliyetlerinde etkin görevler aldığı, eğitim öğretim faaliyetlerinin koordine edilmesi ve sürdürebilmesi için okulda defalarca ders programları hazırladığı ve üst yönetim tarafında sıklıkla istenilen verileri hazırladıkları ortaya çıkmıştır. Bu süreçte çoğunlukla esnek çalışma uygulamasına geçildiği için öğretmenlerden, velilerden ve okullardaki yardımcı personellerden bekledikleri desteği alamadıkları için yöneticilerin iş yüklerinin çok fazla arttığı ve zamanı yönetmekte sorun yaşadıkları belirlenmiştir. Okul yöneticileri yaşadıkları bu sorunlara dayanarak, pandemi sonrasında yöneticilerin sosyal sorumluluk anlayışlarının ve farklı çalışma yöntemlerine ilişkin becerilerin geliştirilmesi gerektiği çıkarımlarında bulunmuşlardır. Benzer şekilde Taşar (2021) tarafından yapılan araştırmada da pandemi sonrasında sosyal yardımlaşma ve dayanışma faaliyetlerine olan ilginin artacağı ve 
esnek/evden çalışma sisteminin yaygınlaşacağının belirlenmesi mevcut araştırma sonuçlarını desteklemektedir.

Covid-19 pandemisi sürecinde insanların kaygı seviyeleri oldukça artmıştır (Öz-Ceviz, TektaşBasmacı ve Tektaş, 2020). Pandemi sürecinde kaygı ve korku gibi duyguların yaratacağı stres durumlarına karşı bireylere destek sağlamak oldukça önemlidir (Gençoğlu ve Çiftçi, 2020). Eğitim paydaşlarında virüse yakalanma, belirsizlik, geleceği öngörememe gibi nedenlere bağlı olarak ortaya çıkan kaygı ve stresin okul yöneticileri açısından çeşitli sorunlar doğurduğu tespit edilmiştir. Pandemi döneminde öğretmenlerin iş yükleri ve aile sorumlulukları artmış; ek olarak yüz yüze eğitime geçilmek istendiğinde öğretmenler, virüse maruz kalma korkusuyla karşı karşıya kalmışlardır (United Nations [UN], 2020). Bu faktörler öğretmenlerde oluşan kaygı ve stresin nedenleri olarak değerlendirilebilir. Araştırmada, okul yöneticilerinin öğrenci, öğretmen ve diğer paydaşlara yeterli psikolojik desteği sağlayamadığı ortaya çıkmıştır. Covid-19 virüsü, görünür olmaması ve bulaş hızının yüksek olması nedenleriyle insanlar üzerinde olumsuz psikolojik etkiler yarattığı gibi temizlik ve hijyeni de daha önemli hale getirmiştir. Mevcut araştırmada okul yöneticilerinin, maske-mesafetemizlik kuralına uyulmaması ve temizlik malzemesi yetersizliği nedenleriyle okullarda temizlik ve hijyen sorunu yaşadıkları saptanmıştır. Benzer şekilde Kavrayıcı ve Kesim (2021) tarafından yapılan araştırmada da pandemi sürecinde okullardaki ödenek eksikliği ve temizlik personeli yetersizliği nedeniyle okul yönetiminin zorlaştığı belirtilmiştir. Buna bağlı olarak okul yöneticileri pandemi sonrası süreçte okullarda hijyene daha fazla önem verilmesi gerektiğini vurgulamışlardır.

Covid-19 pandemisi gibi kriz dönemleri insanlar ve örgütler için çeşitli tehditler oluşturmakla birlikte birçok fırsatın da ortaya çıkmasını sağlayabilmektedir. Bireylerin ve kurumların eksik yönlerinin farkına varması ve bunları gidermesi için fırsatlar doğurabilmektedir. Bu bağlamda eğitim paydaşlarının teknolojik okuryazarlıklarının ve becerilerinin geliştirilmesi ihtiyacına yönelik yüz yüze veya uzaktan eğitim şeklinde Bakanlık veya okul bazlı mesleki ve kişisel gelişim faaliyetlerinin yapılması önerilebilir. Diğer yandan kriz durumlarında eğitim sürecinin devam ettirilebilmesi için Millî Eğitim Bakanlığı tarafından oluşturulan EBA altyapısının geliştirilmesi ve okulların kendi bünyesinde online eğitim altyapılarını oluşturması, içerikler hazırlaması, programlar geliştirmesi gibi çalışmalar yapılabilir. Pandemi sonrası yeni normal dönemde eğitimin yüz yüze ve uzaktan olacak şekilde hibrit modeliyle yürütülmesi paydaşların uzaktan eğitimi benimsemesi açısından etkili olabilir. Okul yöneticilerinin kriz yönetimi, iletişim ve uzaktan okul yönetimi becerilerinin geliştirilmesine yönelik teori ve uygulama odaklı eğitimlere lisansüstü derslerde ve Millî Eğitim Bakanlığının yönetici yetiştirme programlarında yer verilebilir. Son olarak, Bakanlığın ve okulların acil durum eylem planları oluşturması ve gerekli durumlarda okul yöneticilerine yetki devri yapılması önerilebilir. 


\section{Kaynaklar}

Akıncı, M. \& Pişkin-Tunç, M. (2021). Uzaktan eğitim uygulamalarında matematik öğretmen adaylarının karşılaştıkları sorunlar ve çözüm önerileri. EKEV Akademi Dergisi, 25(85), 359-376.

Akkaş-Baysal, E. \& Ocak, G. (2020). Covid-19 salgını sonrasında okul kavramındaki paradigma değişimine ve okulların yeniden açılmasına ilişkin öğretmen görüşleri. Türk Eğitim Bilimleri Dergisi, 18(2), 676-705. doi: 10.37217/tebd.787504

Arastaman, G., Öztürk-Fidan, İ. \& Fidan, T. (2018). Nitel araştırmada geçerlik ve güvenirlik: Kuramsal bir inceleme. Yüzüncü Yıl Üniversitesi Eğitim Fakültesi Dergisi, 15(1), 37-75.

Aytaç, T. (2020). The problems and opinions of school administrators during Covid-19 pandemic: A qualitative study from Turkey. European Journal of Educational Sciences, 7(4), 57-79. doi: $\underline{10.19044 / \text { ejes.v7no4a5 }}$

Başkale, H. (2016). Nitel araştırmalarda geçerlik, güvenirlik ve örneklem büyüklüğünün belirlenmesi. Dokuz Eylül Üniversitesi Hemşirelik Fakültesi Elektronik Dergisi, 9(1), 23-28.

Burke, J. \& Dempsey, M. (2020). Covid-19 practice in primary schools in Ireland report. Ireland: Maynooth University.

Creswell, J. W. (2012). Educational research. NJ: Pearson.

Creswell, J. W. \& Poth, C. N. (2016). Qualitative inquiry and research design: Choosing among five approaches. Thousand Oaks: Sage.

Çakın, M. \& Külekçi-Akyavuz, E. (2020). Covid-19 süreci ve eğitime yansıması: Öğretmen görüşlerinin incelenmesi. International Journal of Social Sciences and Education Research, 6(2), 165-186.

Daniel, S. J. (2020). Education and the COVID-19 pandemic. Prospects, 49, 91-96. doi: 10.1007/s11125$\underline{020-09464-3}$

Domenico, L. D., Pullano, G., Coletti, P., Hens, N. \& Colizza, V. (2020). Expected impact of school closure and telework to mitigate Covid-19 epidemic in France. https://www.epicxlab.com/uploads/9/6/9/4/ 9694133/inserm Covid-19-school-closure.frenchregions 20200313.pdf sayfasından erişilmiştir.

Ersoy, A. F. (2017). Fenomenoloji. A. Saban \& A. Ersoy (Ed.), Eğitimde nitel araştırma desenleri (2. b.) içinde (s. 81-138). Ankara: Anı Yayıncılık.

Frankel, R. M. \& Devers, K. J. (2000). Study design in qualitative research-1: Developing research questions and assessing research needs. Education for Health, 13(2), 251-261.

Gençoğlu, C. \& Çiftçi, M. (2020). Covid-19 salgınında eğitim: Türkiye üzerinden bir analiz. Journal of History School, 46, 1648-1673. doi: $\underline{10.29228 / J o h 44212}$

Güçlü, İ. (2019). Sosyal bilimlerde nitel araştırma yöntemleri: Teknik, yaklaşım, uygulama. Ankara: Nobel. 
Harris, A. (2020). COVID-19-school leadership in crisis? Journal of Professional Capital and Community, 5(3), 321-326. doi: 10.1108/IPCC-06-2020-0045

Harris, A. \& Jones, M. (2020). COVID 19-School leadership in disruptive times. School Leadership $\mathcal{E}$ Management, 40(4), 243-247. doi: $\underline{10.1080 / 13632434.2020 .1811479}$

Hsieh, H. F. \& Shannon, S. E. (2005). Three approaches to qualitative content analysis. Qualitative Health Research, 15(9), 1277-1288.

Kavrayıcı, C. \& Kesim, E. (2021). Covid-19 pandemisi sürecinde okul yönetimi: Nitel bir araştırma. Kuram ve Uygulamada Ĕ̆itim Yönetimi, 27(1), 1005-1060. doi: 10.14527/kuey.2021.004

Keleş, H. N., Atay, D. \& Karanfil, F. (2020). Covid 19 pandemi sürecinde okul müdürlerinin öğretim liderliği davranışları. Milli Eğitim Dergisi, 49(Özel Sayı), 155-174. doi: $\underline{10.37669 / \text { milliegitim.787255 }}$

Konan, N. \& Ulaş, M. M. (2021, Şubat 2-3). Koronavirüs (COVID-19) salgın döneminde anaokulu yöneticisi olmak. Eurasian Conference on Language and Social Sciences'da sunulmuş bildiri, Kosova.

Külekçi-Akyavuz, E. \& Çakın, M. (2020). Covid-19 salgınının eğitime etkisi konusunda okul yöneticilerinin görüşleri. Turkish Studies, 15(4), 723-737. doi: 10.7827/TurkishStudies.44140

McMillan, J. H. (2000). Educational research: Fundamentals for the consumer (3. b.). London: Longman.

Merriam, S. B. (2018). Qualitative research: A guide to design and implementation (Çev. Ed. S. Turan). Ankara: Nobel Yayıncılık.

Metcalfe, L. S. \& Perez, I. (2020). Blinded by the unknown: A school's leader's authentic actions to support teachers and students during COVID-19 school closures. Journal of School Administration Research and Development, 5(SI), 49-54. doi: 10.32674/jsard.v5iS1.2746

Miles, M. B. \& Huberman, A. M. (2015). Nitel veri analizi (Çev. Ed. S. A. Altun \& A. Ersoy). Ankara: Pegem Akademi.

MEB. (2020). Bakan Selçuk, Koronavirüs'e karşı eğitim alanında alınan tedbirleri açıkladı. https://www.meb.gov.tr/bakan-selcuk-koronaviruse-karsi-egitimalaninda-alinan-tedbirleriacikladi/haber/20497/tr,web sayfasından erişilmiştir.

MEB. (2021). 68 bin 241 tablet bilgisayar daha öğrencilere ulaşıyor. https://www.meb.gov.tr/68-bin-241tablet-bilgisayar-daha-ogrencilere-ulasiyor/haber/22656/trr sayfasından erişilmiştir.

Morgan, H. (2020). Best practices for implementing remote learning during a pandemic. The Clearing House, 93(3), 134-140. doi: $\underline{10.1080 / 00098655.2020 .1751480}$

Önan, E. \& Menekay, M. (2021). Covid-19 salgını sürecinde öğretmenlerin mesleki gelişimleri üzerinde okul yöneticilerinin rollerine yönelik algılarının incelenmesi. Journal of Social and Humanities Sciences Research, 8(70), 1299- 1306. doi: $10.26450 /$ jshsr.2468 
Öz-Ceviz, N., Tektaş, N., Basmacı, G. \& Tektaş, M. (2020). Covid 19 pandemi sürecinde üniversite öğrencilerinin kaygı düzeylerini etkileyen değişkenlerin analizi. Uluslararası Ĕ̆itim Araştırmactları Dergisi, 3(2), 312-329.

Özdoğan, A. Ç. \& Berkant, H. G. (2020). Covid-19 pandemi dönemindeki uzaktan eğitime ilişkin paydaş görüşlerinin incelenmesi. Milli Ĕ̆itim Dergisi, 49(Özel Sayı), 13-43. doi: $\underline{10.37669 / m i l l i e g i t i m .788118}$

Özer, M. \& Suna, H. E. (2020). COVID-19 salgını ve eğitim. M. Şeker, A. Özer \& C. Korkut (Ed.), Küresel salgının anatomisi: İnsan ve toplumun geleceğgi içinde (s. 173-192). Ankara: Türkiye Bilimler Akademisi.

Patton, M. (2014). Nitel araştırma ve değerlendirme yöntemleri (Çev. Ed. M. Bütün \& S. B. Demir). Ankara: Pegem Akademi.

Razik, T. A. \& Swanson, A. D. (2001). Fundamental concepts of educational leadership and management. NJ: Prentice Hall.

Reimers, F. M. \& Schleicher, A. (2020). Covid-19 pandemisine karşı eğitimde atılabilecek adımlara rehberlik edecek bir çerçeve. OECD: https://globaled.gse.harvard.edu/files/geii/files/framework guide v4 tr.pdf sayfasından erişilmiştir.

Sarı, E. \& Sarı, B. (2020). Kriz zamanlarında eğitim yönetimi: Covid-19 örneği. Uluslararası Liderlik Çalısmaları Dergisi: Kuram ve Uygulama, 3(2), 49-63.

Sayg1, H. (2021). Covid-19 pandemi uzaktan eğitim sürecinde sınıf öğretmenlerinin karşılaştığ1 sorunlar. Açı̈öğretim Uygulamaları ve Araştırmaları Dergisi, 7(2), 109-129. doi: 10.51948/auad.841632

Shenton, A. K. (2004). Strategies for ensuring trustworthiness in qualitative research projects. Education for Information, 22(2), 63-75.

Stone-Johnson, C. \& Weiner, J. M. (2020). Principal professionalism in the time of COVID-19. Journal of Professional Capital and Community, 5(3/4), 367-374. doi: 10.1108/IPCC-05-2020-0020

Taşar, H. H. (2021). Covid-19 pandemisi sürecinin okul müdürleri üzerindeki etkileri. Kırşehir Eğitim Fakültesi Dergisi, 22(1), 171-196. doi: 10.29299/kefad.808864

TEDMEM. (2020). COVID-19 Sürecinde Eğitim: Uzaktan Öğrenme, Sorunlar ve Çözüm Önerileri (TEDMEM Analiz Dizisi 7). Türk Eğitim Derneği Yayınları.

TEDMEM. (2021). 2020 Eğitim Değerlendirme Raporu (TEDMEM Değerlendirme Dizisi 7). Türk Eğitim Derneği Yayınları.

Turan, S. (2020). Covid-19 sürecinde okul müdürlerinin teknolojik liderliği. Milli Eğgitim Dergisi, 49(Özel Say1), 175-199. doi: 10.37669/milliegitim.788133 
UNESCO. (2020). COVID-19 Educational Disruption and Response. https://en.unesco.org/covid19/ educationresponse sayfasından erişilmiştir.

UN. (2020). Policy Brief: Education during COVID-19 and Beyond. https://www.un.org/development/desa/dspd/wp-content/uploads/sites/22/2020/08/sg policy brief covid-19 and education august 2020.pdf sayfasından erişilmiştir.

Wang, C., Pan, R., Wan, X., Tan, Y., Xu, L., Ho, C. S. \& Ho, R. C. (2020). Immediate psychological responses and associated factors during the initial stage of the 2019 Coronavirus disease (COVID-19) epidemic among the general population in China. International Journal of Environmental Research and Public Health, 17(5), 17-29. doi: 10.3390/ijerph17051729

WHO. (2020). Coronavirus Updates (COVID-19). https://www.who.int/ emergencies/diseases/novelcoronavirus-2019/events-as-they-happen sayfasından erişilmiştir.

Yıldırım, A. \& Şimşek, H. (2016). Sosyal bilimlerde nitel araştırma yöntemleri (10. b.). Ankara: Seçkin.

Yılmaz, E., Güner, B., Mutlu, H. \& Arın-Yılmaz, D. (2020). Farklı öğrenim kademelerindeki öğrencilere verilen uzaktan eğitim hizmetinin veli görüşlerine göre değerlendirilmesi. Milli Eğitim Dergisi, 49(Özel Say1), 477-503. doi: 10.37669/milliegitim.777353

Zizek, S. (2020). Pandemic: COVID-19 shakes the world. New York: OR Books.

\section{Extended Summary}

Major events and pandemics affecting humanity and causing radical changes have taken place during history. The Covid-19 outbreak has been one of the main problems faced by educational systems (Özer and Suna, 2020). All countries in the world were caught unprepared for one of the biggest epidemics in history that deeply overwhelmed their educational systems as well (Daniel, 2020; Wang et al., 2020) and had to close schools to prevent the spread of the pandemic (Domenico et al., 2020). After the World Health Organization (WHO) declared Covid-19 as a pandemic globally on March 11, 2020, the schools were closed worldwide, and educational procedures were fulfilled online and remotely (UNESCO, 2020). The Covid-19 pandemic, which impressed the whole world at the beginning of the twenty-first century, also influenced Turkey. After the diagnosis of the first case in March 2020 in Turkey, it was decided to suspend face-to-face education at schools and exploit distance and online education.

The use of distance and online education as a solution offer to being caught by the pandemic suddenly and unprepared has brought many problems (Morgan, 2020; WHO, 2020). The uncertainty created by the pandemic, the crisis situation, and the unpredictability of the process have become the leading problems faced by schools (Zizek, 2020). While schools are caught unprepared for this rapid change, school administrators need to lead the disruptions in the educational procedures by rapidly 
changing their focus and problem-solving techniques (Keleş et al., 2020). Razik and Swanson (2010) emphasized that effective leadership skills are substantial in crisis management processes in terms of achieving the goals of institutions and stakeholders in sudden crises. School administrators have to struggle with various problems during the crisis period caused by the pandemic. It is observed that a great many problems have been encountered during the distance education process led by the pandemic, such as internet access problems of students and families (Metcalfe and Perez, 2020), shortage of students' technological equipment such as computers and tablets (Haris, 2020), motivating students and communication problems (Çakın and Külekçi-Akyavuz, 2020), anxiety and lack of communication created by uncertainty (Keleş et al. 2020), teachers' inefficacy in the distance education process (Burke and Dempsey, 2020), poor participation of students during the lessons, and the inability to perform measurement and evaluation precisely (Sayg1, 2021). In the study of Kavrayic1 and Kesim (2021), school administrators uttered that there were some challenges in terms of budget, hygiene conditions, and the social and emotional development of students. In the study of Konan and Ulaş (2021), the problems such as the inconsistency for the continuous opening and closure of schools and the perpetual changes in the decisions taken were voiced by the school administrators.

This study, which was carried out to determine the opinions of school administrators about the problems faced by school administrators during the Covid-19 pandemic and the lessons learned, was among those aiming to reveal the existing state of education during the pandemic. It is expected that this study will form a basis for the studies on the effects of the Covid-19 pandemic on education and school management from the perspective of school administrators and its future implications. It is hoped that the opinions of school administrators, who are the implementers of educational policies, regarding the problems they encounter and the lessons they learn will provide rich data about the Covid-19 pandemic period in terms of what should be taken into consideration in the educational system after the pandemic. In this regard, the present study aimed to examine the problems encountered by school administrators during the Covid-19 pandemic and the lessons they learned.

Phenomenology, one of the qualitative research designs, was used in this study as it was aimed to determine the problems experienced by school administrators during the Covid-19 pandemic and the lessons they learned based on their personal experiences. The study group consisted of 21 school administrators working in Gaziantep. The respondents were determined through the maximum diversity sampling method. The diversity of the study group was based on the characteristics such as gender, age, school level, educational background, and management experience. Research data were collected through online interviews with the participants. A semistructured interview form was developed by the researchers for the interviews. The first part of the interview form included the purpose of the research and the questions about the demographics of the 
participants. In the second part of the interview form, there were two open-ended questions and eight probe questions in accordance with the purpose of the study. The research data were collected on a voluntary basis. The interviews lasted between 28 and 64 minutes. The research data were analysed through content analysis. Various strategies were exploited to ensure the validity and reliability of the study.

The problems faced by school administrators during the Covid-19 pandemic were grouped under eight themes: decision making and planning, educational process, technology, communication, workload, motivation, health and hygiene, and crisis management. School administrators mostly experienced the problems of uncertainty caused by the pandemic, ambiguous decisions, late decisions, student absenteeism in distance education, access to distance education, supervision in distance education, internet access, technological equipment shortage of students, failure to provide schoolfamily cooperation, communication with students and families, organizing a class schedule, increased workload of administrators, failure to motivate teachers and students, anxiety and stress of stakeholders.

On the other hand, the lessons learned by school administrators from the challenges they faced during the Covid-19 pandemic were gathered under seven themes: technology, educational process, crisis management, communication, decision making and planning, health and hygiene, and workload. The most crucial lessons that school administrators learned from the problems they experienced during the pandemic were developing teachers' technological competencies, developing students' technology literacy skills, the necessity of school in terms of socialization, designing alternative educational practices, developing crisis management skills, developing distance school management skills, strengthening school-family cooperation, encouraging decentral management practices, attaching more importance to hygiene at schools and developing the social responsibility consciousness of school administrators.

\section{Araştırmacıların Katkı Oranı Beyanı}

$\mathrm{Bu}$ araştırmaya birinci yazar \% 50, ikinci yazar \% 50 oranında katkıda bulunmuştur.

\section{Destek ve Teşekkür Beyanı}

Bu araştırmada herhangi bir kurum, kuruluş ya da kişiden destek alınmamıştır.

\section{Çatışma Beyanı}

Araştırmacıların araştırma ile ilgili diğer kişi ve kurumlarla herhangi bir kişisel ve finansal çıkar çatışması yoktur. 


\section{Etik Kurul Beyanı}

Bu araştırma, Gaziantep Üniversitesi Sosyal ve Beşerî Bilimler Araştırmaları Etik Kurulunun 01.06.2021 tarihli, 49278 sayılı ve 19 numaralı kararı ile yürütülmüştür. 